\title{
Plume-related mafic volcanism and the deposition of banded iron formation
}

\author{
Ann E. Isley \\ Department of Earth Sciences, State University of New York at Oswego \\ Dallas H. Abbott \\ Lamont-Doherty Earth Observatory of Columbia University, Palisades, New York
}

\begin{abstract}
We have compiled a record of the geochronology of mantle plume activity between 3.8 and $1.6 \mathrm{Ga}$. Over this time period, the ages of komatiites, and those of global plumes, correlate strongly, at the $99 \%$ confidence level, with the ages of banded iron formations (BIFs). The ages of continental plumes correlate more weakly, at an overall $85 \%$ confidence level. Using the geochronological records of these events, we can define four periods characterized by mantle superplume activity. Three of these periods are also times of enhanced BIF deposition. The fourth mantle plume period may similarly be coeval with increased BIF accumulation, but the BIF chronostratigraphic resolution is not accurate enough to test this rigorously. Mantle superplume volcanism may promote BIF deposition by increasing the Fe flux to the global oceans through continental weathering and/or through submarine hydrothermal processes. It may also be enhanced by increasing the number of paleotectonic environments appropriate for BIF deposition (particularly plume-induced ocean plateaus, seamounts, and intracratonic rifts) and by promoting global anoxic, Fe-rich hydrothermal plumes in the shallow to intermediate marine water column.
\end{abstract}

\section{Introduction}

Banded iron formations (BIFs) are Precambrian chemical sedimentary rocks deposited in marine environments [James, 1954, 1966]. There are two major types of iron formation defined on the basis of their size and lithologic associations [Gross, 1965]. Algoma-type iron formations are associated with volcanogenic rocks. They are relatively small, with lateral extents $<10 \mathrm{~km}$, and thicknesses of 10-100 m [Gross, 1965; Goodwin, 1973; Appel, 1980; Condie, 1981]. Their estimated initial Fe content rarely exceeds $10^{10} \mathrm{t}$ [James and Trendall, 1982]. Superior-type iron formations are most often associated with other sedimentary units. They were deposited in relatively shallow marine conditions under transgressing seas [Trendall, 1968; Beukes, 1983; Simonson, 1985; Simonson and Hassler, 1996]. Some are hundreds of meters thick. The largest Superior-type BIFs extend over $10^{5} \mathrm{~km}^{2}$ [Trendall and Blockley, 1970; Beukes, 1973], with estimated initial Fe contents exceeding $10^{13} \mathrm{t}$ [James and Trendall, 1982].

The source of the iron deposited in BIFs has been disputed. Researchers have considered both continental and hydrothermal sources [Holland, 1973; Simonson, 1985; Dymek and Klein, 1988; Alibert and McCulloch, 1993]. Both Algoma- and Superior-type BIFs have high-temperature hydrothermal signatures in their trace and rare earth element distributions [Fryer, 1977; Graf, 1978; Dymek and Klein, 1988; Jacobsen and Pimentel-Klose, 1988; Derry and Jacobsen, 1990; Danielson et al., 1992; Klein and Beukes, 1992; Bau and Möller, 1993]. However, the source of the Fe in BIFs is still obscure. The source may have been submarine

Copyright 1999 by the American Geophysical Union.

Paper number $1999 \mathrm{JB} 900066$. 0148-0227/99/1999JB900066\$09.00 hydrothermal or continental (or some combination of both) [Alibert and McCulloch, 1993].

Any sedimentary rock reflects not only the physical, chemical, and biological processes involved in its formation but also the magnitude of the sediment source. The ultimate source of sediment to BIFs is the oceans. Therefore variations in ocean chemistry may have preferentially promoted BIF deposition during some portions of the Precambrian [Gole and Klein, 1981; James and Trendall, 1982; Isley, 1995]. However, it is unclear whether a change in the magnitude of the Fe source is the most important factor in BIF deposition or whether other processes or environmental conditions account for variations in the accumulation rate of BIF through geologic time (for example, biochemical mediation or changes in atmospheric $\mathrm{pO}_{2}$ ).

During mantle plume events the greatest volumes of extrusions are tholeiitic [Garland et al., 1996], which are by definition enriched in iron. A mantle plume situated under subcontinental lithosphere rifts the continental crust and causes the eruption of continental flood basalts [Campbell et al., 1989; Richards et al., 1989; LeCheminant and Heaman, 1989; White and MacKenzie, 1989]. The subsequent erosion of flood basalts, derived from a mantle plume, would increase the riverine flux of $\mathrm{Fe}$ to the global oceans. In the ocean basins, mantle plumes also erupt voluminous tholeiitic basalts and produce oceanic plateaus, aseismic ridges and seamount chains [Larson, 1991a]. Increased production of ocean crust would engender elevated high-temperature hydrothermal activity. Therefore iron derived from Precambrian mantle plume events could be continental and/or oceanic in origin.

If the deposition of BIF is largely controlled by the magnitude of the $\mathrm{Fe}$ source, there should be a temporal correlation between the deposition of iron formation and periods of mantle plume volcanism, as Barley et al. [1997] suggested for the Hamersley BIFs. If the Fe source is predominantly continental, BIF deposition should be 
correlated with mantle plumes confined to continental areas. If the source is predominantly hydrothermal, BIF deposition should be correlated with mantle plumes confined to oceanic lithosphere. In this paper we test these hypotheses by assembling and comparing the geochronological data on mantle plume volcanism and BIF deposition for the time period from 3.8 to $1.6 \mathrm{Ga}$. This interval, encompassing the Archean and Paleoproterozoic, is particularly interesting because more than $90 \%$ of all iron formation was deposited prior to the Paleoproterozoic-Mesoproterozoic boundary [James and Trendall, 1982].

\section{Iron Formations and Hydrothermal Signatures}

Two sets of observations suggest that island arc/back arc basins and/or intracratonic rifts were the paleotectonic setting for Algoma-type BIFs [Gross, 1983; Veizer, 1983]. The first is their association with volcanics spanning a wide range of petrologies, from ultramafic through felsic. The second is the prevalence of geochemical signatures of high-temperature water-rock exchange [Fryer, 1977; Graf, 1978; Dymek and Klein, 1988; Derry and Jacobsen, 1990; Danielson et al., 1992; Bau and Möller, 1993]. Iron was introduced to these deposits by a proximal hydrothermal source.

However, it is more difficult to invoke a hydrothermal source for some of the largest, Superior-type sequences, for example, those of the Hamersley Group and Transvaal Supergroup, which were deposited on the continental shelves of passive tectonic margins [Trendall and Blockley, 1970; Beukes, 1983]. Higher heat flow during the Archean and the Paleoproterozoic could have induced hydrothermal cycling rates 2.5-4 times higher than at the present time [Isley, 1995]. This could account for the accumulation rate of $\mathrm{Fe}$ and $\mathrm{Si}$ in the largest Superior-type BIFs [Derry and Jacobsen, 1990; Isley, 1995]. However, it requires that a significant fraction (10\%) of all $\mathrm{Fe}$ introduced to the water column by submarine hydrothermal processes would have been deposited in the very large class Superior-type iron formations [Isley, 1995]. Furthermore, it is not clear what mechanism translated the geochemical signature of high-temperature water-rock exchange from oceanic hydrothermal vents to continental margins. Some have proposed that upwelling of Fe-enriched deep waters along cratonic margins led to BIF deposition [Holland, 1973; Jacobsen and Pimentel-Klose, 1988]. Others have suggested that BIFs accumulated as a result of upper to mid-ocean circulation of hydrothermal plumes [Morris, 1993. Isley, 1995].

In the modem oceans, high-temperature hydrothermal effluents are diluted by ambient seawater as they ascend buoyantly through the water column. Effluents rise several hundred meters to a level of neutral buoyancy and spread laterally, comprising only $10^{-3}$ to $10^{-4}$ parts of the resultant hydrothermal plume [Lupton et al., 1985; Baker and Massoth, 1987; Little et al., 1987; Speer and Rona, 1989]. While most hydrothermal activity is confined to ridge crests in the deeper portion of the water column, shallow water $(300-1100 \mathrm{~m})$ high-temperature hydrothermal venting has been observed on seamounts associated with mantle plumes and hot spots [Karl et al., 1988; Cheminée et al., 1991]. Some hydrothermal signatures are measureable in plumes over distances of thousands of $\mathrm{km}$ from venting sites (e.g., ${ }^{3} \mathrm{He}, \mathrm{Mn}$ [Lupton and Craig, 1981; Klinkhammer and Hudson, 1986; Lupton, 1996]). Today, Fe rapidly precipitates as sulfides in close proximity to high-temperature venting sites and as amorphous Fe oxides in spreading plumes [Rona, 1984; Nelsen et al., 1986]. In anoxic Archean-Paleoproterozoic oceans, longdistance transport of $\mathrm{Fe}$ by hydrothermal plumes may have been possible [Isley, 1995].

\section{Indicators of Mantle Plume Events}

In order to study ancient mantle plume events it is necessary to understand what types of geologic features are formed during such events. The resulting features are different depending on whether the plume rises beneath continental or oceanic crust. During a mantle plume event beneath an ocean basin, oceanic plateaus and seamounts are formed. Some plateaus and seamounts have such thick crust that they will be accreted rather than subducted [Abbott and Mooney, 1995]. The inferred compositions of the parent magmas that produce oceanic plateaus are komatiitic [Storey et al., 1990]. All komatiites represent relatively high degrees of mantle melting [Abbott et al., 1994], so Archean or Proterozoic komatiites are generally acknowledged to be the product of mantle plumes [Campbell et al., 1989; Campbell and Griffiths, 1990]. If the suboceanic volcanism is sufficiently voluminous, the mantle plume event will also produce a sealevel rise.

Mantle plume events on the continents are characterized by the eruption of continental flood basalts [Richards et al., 1989; Rampino and Caldeira, 1993]. Precambrian flood basalt sequences may also contain komatiites [Blake, 1993; Amelin et al., 1995; Puchtel et al. 1997a]. Like plateau basalts, flood basalts have high iron contents for a given silica content [White and MacKenzie, 1989]. When flood basalts are eroded, the feeder dikes and central layered intrusions are exposed. Thus massive dike swarms and layered intrusions are also the result of subcontinental plume magmatism [LeCheminant and Heaman, 1989; Ernst et al. 1995; Heaman, 1997]. During the Permo-Triassic, a mantle plume event produced enhanced kimberlite and flood basalt activity, but it did not cause a transgression [Larson, 1991b; Haggerty, 1994]. Therefore it appears that mantle plume events largely confined to continents do not produce a sea level rise.

\section{Temporal Variability of Mantle Plume Volcanic Associations}

As described in section 3, depending on whether they are situated beneath oceanic or continental lithosphere, mantle plume events leave different signatures in the geologic record. One may infer that because only a fraction of the continental surface area had formed in the Early-Middle Archean [Taylor and McLennan, 1985], the likelihood of suboceanic mantle plume volcanism was greater during that interval. Oceanic plume events would have been expressed through the formation of oceanic plateaus and seamounts incorporating high $\mathrm{Fe}$ (tholeiitic) magmas and komatiitic volcanics and with a lithospheric buoyancy that impeded their subduction [BenAvrahim et al., 1981; Richards et al., 1991; Abbott and Mooney, 1995].

In the Late Archean, continental growth was very rapid, producing a large surface area suitable for continental flood basalt magmatism [Taylor and McLennan, 1985]. Continents also became more emergent in the Late Archean [Wise, 1974; Reymer and Schubert, 1986]. Thus, during the Archean the probability that continental flood basalts would form was progressively increasing. Subsequently, these basalts would have been eroded, exposing their underlying basal layered intrusions and feeder dikes. Therefore we would expect to find an increasing number of continental flood basalts, massive dike swarms, and layered intrusions in the Late Archean and Paleoproterozoic.

We have not made any effort to correct the records for the biases arising from such secular changes in Earth's crust. We assumed in this compilation that mantle plume events that left a dominantly oceanic record would be represented by the temporal distribution of those komatiites that are not 
Table 1. Locations and Ages of Komatiites

\begin{tabular}{|c|c|c|c|c|}
\hline Craton & Location of Komatiite Units & Age or Age Constraint, Ma & Method & References \\
\hline $\begin{array}{l}\text { Kaapvaal } \\
\text { Kaapvaal }\end{array}$ & $\begin{array}{l}\text { Dwalile Greenstone Belt } \\
\text { Barberton Mountain Land: Songimvelo and } \\
\text { Steynsdorp Blocks, Lower Onverwacht, }\end{array}$ & $\begin{array}{l}3521 \pm 23 \text { and } 3436 \pm 5 \\
3472 \pm 5 \text { and } 3458 \pm 2\end{array}$ & $\begin{array}{l}\mathrm{Pb}-\mathrm{Pb} \\
\mathbf{U}-\mathrm{Pb}\end{array}$ & $\begin{array}{l}\text { Kröner and Tegtmeyer [1994] } \\
\text { Armstrong et al. [1990] and } \\
\text { Kamo and Davis [1994] }\end{array}$ \\
\hline Pilbara & Warrawoona Group, Salgash Subgroup & $\begin{array}{l}\text { Lower Komatii Formation } \\
3462 \pm 2 \text { and } 3431 \pm 4\end{array}$ & $\mathbf{U}-\mathbf{P b}$ & $\begin{array}{l}\text { McNaughton et al. }[1993] \text { and } \\
\text { Boulter et al. }[1987]\end{array}$ \\
\hline $\begin{array}{l}\text { Kaapvaal } \\
\text { Kaapvaal }\end{array}$ & $\begin{array}{l}\text { Nondweni Greenstone Belt } \\
\text { Barberton Mountain Land: Songimvelo and } \\
\text { Steynsdorp Blocks, Upper Komatii and } \\
\text { Hoogenoog Formations }\end{array}$ & $\begin{array}{l}3406 \pm 3 \\
3352 \pm 6\end{array}$ & $\begin{array}{l}\mathrm{U}-\mathrm{Pb} \\
\mathrm{U}-\mathrm{Pb}\end{array}$ & $\begin{array}{l}\text { Wilson and Versfeld [1994] } \\
\text { Kamo and Davis [1994] }\end{array}$ \\
\hline $\begin{array}{l}\text { Kaapvaal } \\
\text { Kaapvaal }\end{array}$ & $\begin{array}{l}\text { Commondale Greenstone Belt } \\
\text { Barberton Mountain Land: Umuduha Block, } \\
\text { Upper Onverwacht, Mendon Formation }\end{array}$ & $\begin{array}{l}3334 \pm 18 \\
3298 \pm 6\end{array}$ & $\begin{array}{l}\text { Sm-Nd } \\
\mathrm{Pb}-\mathrm{Pb}\end{array}$ & $\begin{array}{l}\text { Wilson and Carlson [1989] } \\
\text { Byerly et al. [1996] }\end{array}$ \\
\hline Kaapvaal & $\begin{array}{l}\text { Barberton Mountain Land: Kaap Valley } \\
\text { Block, Upper Ontverwacht, Weltevreden } \\
\text { Formation }\end{array}$ & $3286 \pm 29$ & Sm-Nd & Lahaye et al. [1995] \\
\hline Pilbara & Regal Supersequence, Roebum Belt & $3112 \pm 6$ and $2990 \pm 7$ & $\mathrm{U}-\mathrm{Pb}$ & $\begin{array}{l}\text { Krapez [1993] and } \\
\text { McNaughton et al. }\end{array}$ \\
\hline Aldan & Olondo Greenstone Beht & $3070 \pm 55$ & Sm-Nd & $\begin{array}{l}\text { Velikoslavinsky et al. [1993] } \\
\text { (citing A. A. Nemchin) }\end{array}$ \\
\hline Superior & $\begin{array}{l}\text { North Spirit Lake Greenstone Belt, Sachigo } \\
\text { Subprovince (lower supracrustal sequence) }\end{array}$ & $3023 \pm 2$ and $2986+3 /-2$ & $\mathrm{U}-\mathrm{Pb}$ & Corfu and Wood [1986] \\
\hline $\begin{array}{l}\text { Superior } \\
\text { Superior } \\
\text { Yilgarn } \\
\text { Baltica } \\
\text { Superior } \\
\text { Saó Francisco }\end{array}$ & $\begin{array}{l}\text { Lumby Lake Greenstone Belt } \\
\text { Red Lake Greenstone Belt, Uchi Subprovince } \\
\text { Lake Johnston Greenstone Belt } \\
\text { Kostomuksha Greenstone Belt } \\
\text { Vizien Greenstone Belt, Minto Block } \\
\text { Rio das Velhas Greenstone Belt, Nova Lima } \\
\text { Group }\end{array}$ & $\begin{array}{l}2999.4 \pm 2.9 \text { and } 2906 \pm 3 \\
2997.5 \pm 14.5 \text { and } 2893.7 \pm 1.2 \\
2921 \pm 4 \text { and } 2903 \pm 5 \\
2843 \pm 39 \\
2784 \pm 57 \\
2782.5 \pm 16.5 \text { and } 2776.5 \pm 6.5\end{array}$ & $\begin{array}{l}\mathrm{U}-\mathrm{Pb} \\
\mathrm{U}-\mathrm{Pb} \\
\mathrm{U}-\mathrm{Pb} \\
\mathrm{Sm}-\mathrm{Nd} \\
\mathrm{Sm}-\mathrm{Nd} \\
\mathrm{U}-\mathrm{Pb}\end{array}$ & $\begin{array}{l}\text { Davis and Jackson [1988] } \\
\text { Corfu and Wallace [1986] } \\
\text { Wang et al. [1996] } \\
\text { Puchtel et al. [1997b] } \\
\text { Skulski and Percival [1996] } \\
\text { Machado et al. [1992] }\end{array}$ \\
\hline $\begin{array}{l}\text { Pilbara } \\
\text { Superior }\end{array}$ & $\begin{array}{l}\text { Fortescue Group, Pyradie Formation } \\
\text { Michipicoten Greenstone Belt, Wawa } \\
\text { Subprovince (lower supracrustal sequence) }\end{array}$ & $\begin{array}{l}2756 \pm 8 \text { and } 2715 \pm 6 \\
2749 \pm 2 \text { and } 2744 \pm 10\end{array}$ & $\begin{array}{l}\mathrm{U}-\mathrm{Pb} \\
\mathrm{U}-\mathrm{Pb}\end{array}$ & $\begin{array}{l}\text { Arndt et al. }[1991] \\
\text { Turek et al. }[1982]\end{array}$ \\
\hline Superior & Abitibi Greenstone Belt, Wabewawa Group & $2747 \pm 2$ and $2720 \pm 2$ & $\mathrm{U}-\mathrm{Pb}$ & $\begin{array}{l}\text { Morlensen [1993] and } \\
\text { Corfu and Noble [1992] }\end{array}$ \\
\hline Superior & $\begin{array}{l}\text { Shebandowan Greenstone Belt, Wawa } \\
\text { Subprovince }\end{array}$ & $2733 \pm 3$ and $2689+3 /-2$ & $\mathrm{U}-\mathrm{Pb}$ & Corfu and Stont [1986] \\
\hline Superior & $\begin{array}{l}\text { Abitibi Greenstone Belt, Stoughton- } \\
\text { Roquemaure Group }\end{array}$ & $2714 \pm 2$ and $2713+7 /-5$ & $\mathrm{U}-\mathrm{Pb}$ & $\begin{array}{l}\text { Corfu [1993] and } \\
\text { Corfu and Noble [1992] }\end{array}$ \\
\hline Kaapvaal & $\begin{array}{l}\text { Ventersdorp Supergroup, Klipriviersburg } \\
\text { Group }\end{array}$ & $2713.5 \pm 8$ & $\mathrm{U}-\mathrm{Pb}$ & Armstrong et al. [1991] \\
\hline Superior & Abitibi Greenstone Belt, Larder Lake Group & $2705 \pm 2$ & $\mathrm{U} \cdot \mathrm{Pb}$ & Corfu et al. [1989] \\
\hline Superior & $\begin{array}{l}\text { Abitibi Greenstone Belt, Lower Tisdale } \\
\text { Formation }\end{array}$ & $2702.5 \pm 2.5$ & $\mathrm{U}-\mathrm{Pb}$ & Corfu et al. [1989] \\
\hline Yilgam & Kambalda Komatiite Formation & $2702 \pm 4$ and $2692 \pm 4$ & $\mathrm{U}-\mathrm{Pb}$ & $\begin{array}{l}\text { Campbell and Hill [1988] and } \\
\text { Claoué-Long et al. [1988] }\end{array}$ \\
\hline Zimbabwe & $\begin{array}{l}\text { Belingwe Greenstone Belt, Zvishevane } \\
\text { region, Reliance Formation }\end{array}$ & $2690 \pm 13$ & $\mathrm{~Pb}-\mathrm{Pb}$ & Nisbet et al. [1987] \\
\hline $\begin{array}{l}\text { Sino-Korea } \\
\text { Baltica } \\
\text { Baltica } \\
\text { Nain } \\
\text { Guiana } \\
\text { Baltica } \\
\text { Superior } \\
\text { Amazonia } \\
\text { Superior } \\
\text { Yavapai-Mazatzal }\end{array}$ & $\begin{array}{l}\text { Hebei Province } \\
\text { Suomussalmi Greenstone Belt } \\
\text { Vetreny Belt, Vetreny Suite } \\
\text { Mugford Group, Labrador } \\
\text { Paramaca Series } \\
\text { Karasjok Komatiite } \\
\text { Cape Smith Fold Belt, Purtiniq Ophiolite } \\
\text { Alto Jauru Greenstone Belt } \\
\text { Trans-Hudson Orogen, Ottawa Islands } \\
\text { Salida Area, Colorado }\end{array}$ & $\begin{array}{l}2660 \pm 75 \\
2660 \pm 40 \\
2430 \pm 54 \\
2369 \pm 55 \\
2110 \pm 90 \\
2085 \pm 85 \\
1998 \pm 2 \\
1988 \pm 45 \\
1790 \pm 80 \\
1728 \pm 6 \text { and } 1672 \pm 5\end{array}$ & $\begin{array}{l}\text { Sm-Nd } \\
\mathrm{Pb}-\mathrm{Pb} \\
\mathrm{Sm}-\mathrm{Nd} \\
\mathrm{Rb}-\mathrm{Sr} \\
\mathrm{Sm}-\mathrm{Nd} \\
\mathrm{Sm}-\mathrm{Nd} \\
\mathrm{U}-\mathrm{Pb} \\
\mathrm{Sm}-\mathrm{Nd} \\
\mathrm{Pb}-\mathrm{Pb} \\
\mathrm{U}-\mathrm{Pb}\end{array}$ & $\begin{array}{l}\text { Jahn and Ernst [1990] } \\
\text { Vidal et al. [1980] } \\
\text { Puchtel et al. [1997a] } \\
\text { Barton [1975] } \\
\text { Gruau et al. [1985] } \\
\text { Krill et al. }[1985] \\
\text { Parrish [1989] } \\
\text { Pinho et al. [1997] } \\
\text { Arndt and Todt [1994] } \\
\text { Bickford et al. }[1989]\end{array}$ \\
\hline
\end{tabular}

'Assuming extrusives contemporaneous with intrusives [Pyke, 1982]

associated with continental flood basalts and that mantle plumes situated under continental lithosphere would have produced flood basalts, dikes, and layered intrusions. In cases where mantle plume magmatism appears to have occurred in both oceanic and continental regions, or to have influenced several cratons simultaneously, we have used the term superplume to indicate an especially large event.

\section{Criteria for Selection of Mantle Plume Sequences}

In our database we have tabulated geochronological information for four proxies of mantle plume activity: komatiites, flood basalts, mafic dike swarms, and layered mafic intrusions. Archean-Paleoproterozoic komatiites occur 
Table 2. Description of Archean and Paleoproterozoic Flood Basalt Sequences

\begin{tabular}{|c|c|c|c|c|c|c|c|}
\hline Craton & Sequence & Age, Ma & $\begin{array}{c}\text { Duration of } \\
\text { Volcanism, Myr }\end{array}$ & $\begin{array}{l}\text { Extrusive } \\
\text { Rock Type }\end{array}$ & Area, $\mathbf{k m}^{2}$ & $\begin{array}{l}\text { Maximum } \\
\text { Thickness, } \mathrm{m}\end{array}$ & References \\
\hline Kaapvaal & $\begin{array}{l}\text { Ventersdorp } \\
\text { Supergroup }\end{array}$ & $\begin{array}{c}2713.5 \pm 8 \text { to } \\
2709 \pm 4\end{array}$ & ca. 1 - 15 & $\begin{array}{l}\text { tholeiitic, } \\
\text { high-Mg, } \\
\text { komatiitic } \\
\text { basalt, } \\
\text { komatiite }\end{array}$ & $>2 \times 10^{5}$ & 5775 & $\begin{array}{l}\text { Winter [1976], } \\
\text { Armstrong et al. [1991], } \\
\text { and Nelson et al. [1992] }\end{array}$ \\
\hline Pilbara & $\begin{array}{c}\text { Fortescue } \\
\text { Group }\end{array}$ & $\begin{array}{c}2775 \pm 10 \text { to } \\
2715 \pm 6\end{array}$ & $40-75$ & $\begin{array}{l}\text { tholeiitic, } \\
\text { high-Mg } \\
\text { basslt and } \\
\text { komatiite }\end{array}$ & $1.12 \times 10^{5}$ & 7600 & $\begin{array}{l}\text { Blake and Grooves [1987], } \\
\text { Thorne and Blake } \\
\text { [1990], and Blake } \\
\text { [1993] }\end{array}$ \\
\hline Baltica & $\begin{array}{l}\text { Karelian } \\
\text { Supergroup, } \\
\text { Sumi-Sariola } \\
\text { Group }\end{array}$ & $\begin{array}{r}2442.1 \pm 1.4 \text { to } \\
2441.3 \pm 1.2\end{array}$ & $<4$ & $\begin{array}{l}\text { basalts, } \\
\text { andesites, } \\
\text { komatiites } \\
\text { minor } \\
\text { felsic rocks }\end{array}$ & order of $10^{4}$ & $2000-2500$ & $\begin{array}{l}\text { Amelin et al. [1995], } \\
\text { and Puchtel et al. [1991] }\end{array}$ \\
\hline Baltica & $\begin{array}{l}\text { Imandra- } \\
\text { Varzuga } \\
\text { Supergroup, } \\
\text { Strelna } \\
\text { Group }\end{array}$ & $2442.8 \pm 4.8$ & ca. 8 & $\begin{array}{l}\text { basalts, } \\
\text { andesites, } \\
\text { minor } \\
\text { felsic rocks }\end{array}$ & order of $10^{4}$ & $6500-8400$ & Amelin et al. [1995] \\
\hline Baltica & Onega Plateau & $\begin{array}{r}1976 \pm 9 \text { and } \\
1975 \pm 24\end{array}$ & $<20-48$ & basalts & $6 \times 10^{6}$ & 4500 & Puchtel et al. [1999] \\
\hline
\end{tabular}

either in greenstone belts or in mafic units interpreted as flood basalts (Table 1). As discussed in section 4, komatiitic eruptions result from mantle plume volcanism [Campbell et al., 1989; Campbell and Griffiths, 1990, 1992; Storey et al., 1990; Abbott et al. 1994]. Each of the continental flood basalts in Table 2 has been attributed to mantle plume activity, and three of the four contain komatiitic units [Blake, 1993; Amelin et al., 1995; Puchtel et al., 1997a].

In addition, we have compiled the ages of ultramafic dike swarms and layered intrusions. These features do not necessarily require a mantle plume or hot spot origin. Nevertheless, several of the large/giant mafic dyke swarms listed in Table 3 have been attributed to mantle plume volcanism [Ernst et al., 1995]. Others may have been conduits for flood basalts that have since been eroded (e.g., the Widgiemooltha Dike Swarm). Additionally, most of the layered mafic intrusions cited in Table 4 are enriched in platinum group elements (PGEs). Because PGEs are incompatible elements, PGE enrichment in magmas also requires a high degree of partial melting, which is consistent with their derivation from a mantle plume source.

\section{Compiling the Ages of Mantle Plume Events}

In order to define periods of mantle plume events between 3.8 and $1.6 \mathrm{Ga}$ we have compiled published data on the ages of rocks formed by mantle plume activity which we use as proxies to date mantle plume events. That is, we compiled geochronological data on the ages of komatiites and associated basalts (Table 1), continental flood basalts (Table 2), continental dike swarms (Table 3), and layered mafic intrusions (Table 4).

For each terrain in the database we incorporated the most accurate geochronological data available. In those instances where komatiites are interbedded with felsic volcanics, zircon separates can be obtained from the felsic rocks and analyzed using U.Pb isotopic techniques. In other cases, mineral separates of baddeleyite, another zirconium mineral, have been dated via $\mathrm{U}-\mathrm{Pb}$. However, in many cases, only whole rock analyses with $\mathrm{Sm}-\mathrm{Nd}, \mathrm{Pb}-\mathrm{Pb}$, or $\mathrm{Rb}-\mathrm{Sr}$ isotopes provide the age constraints for komatiites and their associated rocks (Table 1).

Continental flood basalt sequences often contain felsic members from which zircons can be obtained, permitting the use of more accurate U-Pb techniques. Consequently, in Table 2 , there is only one flood basalt sequence with an age uncertainty of more than 10 Myr. A smaller percentage of the mafic dike swarms listed in Table 3 and the layered igneous intrusions listed in Table 4 have ages constrained by U-Pb isotopic analyses on zircons or other mineral separates. Other dates have been derived from whole rock analyses using $\mathrm{Sm}$ $\mathrm{Nd}$, Rb-Sr, or K-Ar techniques. Consequently, there are much greater uncertainties in the ages of these rocks.

\section{Iron Formation Lithological Associations}

As discussed in section 1, the classification of a sequence of banded iron formation as Algoma-type or Superior-type depends upon its presumed paleodepositional environment, as deduced from geochemical, stratigraphical, structural, and other studies. New information might cause a reevaluation of a depositional environment, and there are many BIFs that do not fit either category perfectly. For example, the Algoma-type BIF is supposed to include those associated with volcanic rocks, but it has been applied to sequences containing a wide range of volcanic petrologies, from ultramafic through felsic. Many Algoma-type BIFs are thin layers or lenses interbedded with or intercalated with (ultra)mafic volcanics erupted in a marine environment. The volcanics may have chemical affinities to ocean island basalts (OIBs), enriched mid-ocean ridge basalts (MORBs), or normal MORBs (NMORBs) [Hoffman, 1988]. The ages of the volcanics and their associated BIF units are often statistically the same [Blum and Crocket, 1992; Jackson et al., 1994; Stevenson, 1995]. Units from the Barberton Mountain Land also contain massive sulfides or collapsed hydrothermal chimney deposits, indicating there was a proximal, high-temperature hydrothermal source for the Fe [deWit et al., 1992; de Ronde et al., 1994]. 
Table 3. Locations and Ages of Mafic Dike Sequences

\begin{tabular}{|c|c|c|c|c|c|}
\hline Craton & Name of Swarm & Rock Type & Age, $\mathrm{Ma}$ & Method & References \\
\hline $\begin{array}{l}\text { Limpopo } \\
\text { Wyoming } \\
\text { Wyoming } \\
\text { Baltica } \\
\text { Baltica } \\
\text { Superior } \\
\text { Kaapvaal } \\
\text { Superior } \\
\text { Lewisian } \\
\text { Yilgam } \\
\text { Antarctica } \\
\text { Antarctica } \\
\text { Nain } \\
\text { Slave } \\
\text { Superior } \\
\text { Superior } \\
\text { Wyoming } \\
\text { Dharwar } \\
\text { Superior } \\
\text { Nain } \\
\text { Superior } \\
\text { Superior } \\
\text { India } \\
\text { Lewisian } \\
\text { Nain } \\
\text { India } \\
\text { Kaapvaal } \\
\text { Superior } \\
\text { Baltica } \\
\text { Baltica } \\
\text { Antarctica } \\
\text { Kaapvaal } \\
\text { Yavapai- Mazatzal } \\
\text { India } \\
\text { Dharwar } \\
\text { Nain }\end{array}$ & $\begin{array}{l}\text { unnamed } \\
\text { Bighom I } \\
\text { Stillwater } \\
\text { Belomorian } \\
\text { Belomorian } \\
\text { Matachewan } \\
\text { Great Dyke } \\
\text { Hearst } \\
\text { Scourie I } \\
\text { Widgiemooltha" } \\
\text { Vestfold Hills I } \\
\text { Vestfold Hills II } \\
\text { Kikkertavak } \\
\text { Malley-McKay } \\
\text { Senneterre } \\
\text { Nippissing } \\
\text { Bighom Dikes II } \\
\text { unnamed } \\
\text { Biscotasing } \\
\text { MD } \\
\text { Marathon } \\
\text { Ft. Frances } \\
\text { Cuddapah Basin } \\
\text { Scourie II } \\
\text { Kangâniut/Uimvitk } \\
\text { Cuddapah Basin } \\
\text { unnamed } \\
\text { Molson } \\
\text { Sweden-Bothnia } \\
\text { Pechenga, Kola } \\
\text { Vestfold Hills III } \\
\text { unnamed } \\
\text { sheeted, ophiolite } \\
\text { Cuddapah Basin } \\
\text { unnamed } \\
\text { Melville Bugt }\end{array}$ & $\begin{array}{l}\text { basaltic komatiite } \\
\text { (meta)dolerite } \\
\text { ultramafic } \\
\text { gabbro-norite } \\
\text { diorite } \\
\text { Fe-rich quartz tholeiites } \\
\text { ultramafic with PGE } \\
\text { Fe-rich quartz tholeiites } \\
\text { picrites and norites } \\
\text { gabbro, norite, harzburgite } \\
\text { high-Mg tholeites } \\
\text { high-Mg norites } \\
\text { tholeiites and gabbros } \\
\text { diabase } \\
\text { quartz tholeiites } \\
\text { diabase } \\
\text { dolerite } \\
\text { tholeiites } \\
\text { quartz tholeiites } \\
\text { dolerites } \\
\text { diabase } \\
\text { diabase } \\
\text { tholeiites } \\
\text { tholeiites, olivine gabbros } \\
\text { tholeiites } \\
\text { tholeiites } \\
\text { ultramafic } \\
\text { komatiitic, tholeiitic basalt } \\
\text { tholeiitic within plate basalt } \\
\text { picrites } \\
\text { high-Mg tholeiites } \\
\text { tholeiites } \\
\text { gabbro } \\
\text { tholeiites } \\
\text { dolerite-gabbro-norite } \\
\text { dolerites and gabbros }\end{array}$ & $\begin{array}{l}3005 \pm 61 \\
2826 \pm 58 \\
2713 \pm 3 \\
2692 \pm 1.6 \\
2657 \pm 6.4 \\
2476.5 \pm 12.5 \\
2461 \pm 16 \\
2446 \pm 3 \\
2418+7 /-4 \\
2411 \pm 38 \\
2350 \pm 48 \\
2241 \pm 4 \\
2235 \pm 2 \\
2220 \pm 10 \\
2214.3 \pm 12.4 \\
2213.8 \pm 7.4 \\
2200 \pm 35 \\
2193 \pm 45 \\
2166.7 \pm 1.4 \\
2130 \pm 65 \\
2114.5 \pm 10.5 \\
2076.5 \pm 4.5 \\
2068 \pm 79 \\
1992+3 /-2 \\
1950 \pm 60 \\
1938 \pm 75 \\
1910 \pm 60 \\
1883 \pm 2 \\
1881 \pm 8 \\
1880 \pm 55 \\
1754 \pm 16 \\
1740 \pm 30 \\
1738 \pm 5 \\
1713 \pm 65 \\
1667 \pm 32 \\
1645 \pm 35\end{array}$ & $\begin{array}{l}\text { Rb-Sr } \\
\text { Rb-Sr } \\
\text { U-Pb } \\
\text { U-Pb } \\
\text { U-Pb } \\
\text { U-Pb } \\
\text { Sm-Nd } \\
\text { U-Pb } \\
\text { U-Pb } \\
\text { Sm-Nd } \\
\text { Rb-Sr } \\
\text { U-Pb } \\
\text { U-Pb } \\
\text { U-Pb } \\
\text { U-Pb } \\
\text { U-Pb } \\
\text { Rb-Sr } \\
\text { K-Ar } \\
\text { U-Pb } \\
\text { Rb-Sr } \\
\text { U-Pb } \\
\text { U-Pb } \\
\text { K-Ar } \\
\text { U-Pb } \\
\text { Rb-Sr } \\
\text { K-Ar } \\
\text { Rb-Sr } \\
\text { U-Pb } \\
\text { U-Pb } \\
\text { Rb-Sr } \\
\text { U-Pb } \\
\text { K-Ar } \\
\text { U-Pb } \\
\text { K-Ar } \\
\text { K-Ar } \\
\text { Rb-Sr }\end{array}$ & $\begin{array}{l}\text { Barton et al. [1983] } \\
\text { Steuber et al. [1976] } \\
\text { Premo et al. [1990] } \\
\text { Lobach-Zhuchenko et al. [1994] } \\
\text { Lobach-Zhuchenko et al. [1994] } \\
\text { Heaman [1997] } \\
\text { Wilson and Prendergast [1989] } \\
\text { Heaman [1997] } \\
\text { Heaman and Tarney [1989] } \\
\text { Fletcher et al. [1987] } \\
\text { Sheraton and Black [1981] } \\
\text { Lanyon et al. [1992] } \\
\text { Cadman et al. [1993] } \\
\text { LeCheminant et al. }[1996] \\
\text { Buchan et al. [1993] } \\
\text { Noble and Lightfoot [1992] } \\
\text { Steuber et al. [1976] } \\
\text { Balasubrahmanyan [1975] } \\
\text { quoted by Murthy [1987] } \\
\text { Buchan et al. }[1996] \\
\text { Kalsbeek and Taylor [1985] } \\
\text { Buchan et al. [1996] } \\
\text { Buchan et al. [1996] } \\
\text { Murty et al. [1987] } \\
\text { Heaman and Tarney [1989] } \\
\text { Kalsbeek et al. [1978] } \\
\text { Murty et al. [1987] } \\
\text { Hunter and Reid [1987] } \\
\text { Heaman et al. [1986] } \\
\text { Wikstrom et al. [1996] } \\
\text { Skufin [1994] } \\
\text { Lanyon et al. [1992] } \\
\text { Hunter and Reid [1987] } \\
\text { Dann et al. [1989] } \\
\text { Murty et al. [1987] } \\
\text { Radhakrishna et al. [1986] } \\
\text { Kalsbeek and Taylor [1986] }\end{array}$ \\
\hline
\end{tabular}

'Includes Jimberlana and Binneringie Dikes.

Table 4. Locations and Ages of Layered Ultramafic Intrusions

\begin{tabular}{|c|c|c|c|c|}
\hline Craton & Layered (Ultra)Mafic Intrusion & Age, Ma & Method & References \\
\hline $\begin{array}{l}\text { Limpopo } \\
\text { Yilgam } \\
\text { Superior } \\
\text { Kaapvaal } \\
\text { Nain } \\
\text { Yilgam } \\
\text { Kaapvaal } \\
\text { Superior }\end{array}$ & $\begin{array}{l}\text { Messina Layered Intrusion } \\
\text { Munni Munni Intrusion } \\
\text { Otuer Creek Layered Igneous Intrusion } \\
\text { Ushushwana Intrusion" } \\
\text { Fiskanaesset Anorthosite Complex } \\
\text { Millindinna Complex } \\
\text { Rooiwater Complex } \\
\text { Lac des Iles Complex }\end{array}$ & $\begin{array}{l}3153 \pm 47 \\
2925 \pm 16 \\
2890 \pm 90 \\
2875 \pm 40 \\
2870 \pm 70 \\
2830 \pm 20 \\
2740 \pm 4 \\
2738 \pm 27\end{array}$ & $\begin{array}{l}\text { Rb-Sr } \\
\text { U-Pb } \\
\text { Sm-Nd } \\
\text { Rb-Sr and Sm-Nd } \\
\text { Sm-Nd } \\
\text { Sm-Nd } \\
\text { U-Pb } \\
\text { Rb-Sr }\end{array}$ & $\begin{array}{l}\text { Barton et al. [1979] } \\
\text { Arndt et al. [1991] } \\
\text { Windom et al. [1993] } \\
\text { Layer et al. [1988] } \\
\text { Ashwal et al. [1986] } \\
\text { Korsch and Gulson [1986] } \\
\text { Poujol et al. [1996] } \\
\text { Brigmann and Naldrett } \\
\quad \text { [1987] }\end{array}$ \\
\hline $\begin{array}{l}\text { Wyoming } \\
\text { Superior } \\
\text { Baltica } \\
\text { Baltica } \\
\text { Baltica } \\
\text { Baltica } \\
\text { Baltica }\end{array}$ & $\begin{array}{l}\text { Stillwater Complex } \\
\text { Kamiskotia Layered Mafic Intrusion } \\
\text { Monche Pluton } \\
\text { Mount Generalaskaya } \\
\text { Fedorovy-Pansky } \\
\text { Burakovsky Layered Intrusion } \\
\text { Oulanka Layered Complex }\end{array}$ & $\begin{array}{l}2705 \pm 4 \\
2702 \pm 2 \\
2504 \pm 1.5 \\
2502 \pm 1.6 \\
2470 \pm 9 \\
2445 \pm 4 \\
2444 \pm 3.5\end{array}$ & $\begin{array}{l}\text { U-Pb } \\
\text { U-Pb } \\
\text { U-Pb } \\
\text { U-Pb } \\
\text { U-Pb } \\
\text { Pb-Pb } \\
\text { U-Pb }\end{array}$ & $\begin{array}{l}\text { Premo et al. }[1990] \\
\text { Barrie and Davis [1990] } \\
\text { Amelin et al. [1995] } \\
\text { Amelin et al. }[1995] \\
\text { Balashov et al. [1993] } \\
\text { Sharkov et al. [1995] } \\
\text { Balashov et al. [1993], and } \\
\quad \text { Amelin et al. }[1995]\end{array}$ \\
\hline $\begin{array}{l}\text { Baltica } \\
\text { Yilgam } \\
\text { Baltica } \\
\text { Kaapvaal } \\
\text { Superior } \\
\text { Superior }\end{array}$ & $\begin{array}{l}\text { Imandra Lopolith } \\
\text { Jimberlana Dyke } \\
\text { Penikat Layered Intrusion } \\
\text { Bushveld Layered Intrusion } \\
\text { Kaviniq Sills } \\
\text { Fox River Sill }\end{array}$ & $\begin{array}{l}2441 \pm 1.6 \\
2411 \pm 38 \\
2410 \pm 64 \\
2061 \pm 27 \\
1920 \pm 8 \\
1883 \pm 1.4\end{array}$ & $\begin{array}{l}\text { U-Pb } \\
\text { Sm-Nd } \\
\text { Sm-Nd } \\
\text { Rb-Sr } \\
\text { U-Pb } \\
\text { U-Pb }\end{array}$ & $\begin{array}{l}\text { Amalin et al. [1995] } \\
\text { Fletcher et al. [1987] } \\
\text { Huhma et al. [1990] } \\
\text { Walraven et al [1990] } \\
\text { Parrish [1989] } \\
\text { Heaman et al. [1986] }\end{array}$ \\
\hline
\end{tabular}

"The Ushushwana layered intrusion is frequently considered a dike. In fach it is a crescent-shaped north-south oriented intrusion. The southernmost portion intrudes the Insuzi Group as a gabbro/granophyre sill. The northemmost portion is a dike with eight cumulate layers including pyroxenite [Layer et al., 1988]. 
Other Algoma-type BIFs, for example, the Boston Iron Formation and the Helen Iron Formation (Superior Craton), have greater thicknesses (some of which exceed $1 \mathrm{~km}$ ) but are also intercalated with volcanic flows and pyroclastics. These thicker BIFs also occur in associations with a range of volcanic compositions, from (ultra)mafic through felsic [Card, 1990; Blum and Crocket, 1992; Jackson et al., 1994]. The 1.9 Ga BIFs deposited at Bergslagen, which are quartz-banded iron ores interbedded with rhyolite ash-siltstones [Allen et al., 1996], are also considered "Algoma-type" [Oen, 1987]. Given the variations in the lithological associations of this category of BIF, the two favored paleotectonic models for iron formation deposition (island arc/back arc basin [Veizer, 1983] or intracratonic rift [Gross, 1983]) may not be appropriate for occurrences of all Algoma-type BIFs.

The sedimentary associations of Superior-type sequences indicate that they were deposited on the continental shelves of passive tectonic margins [Gross, 1965]. This model suits the BIFs of the Hamersley Group and the Transvaal Supergroup very well [Trendall and Blockley, 1970; Beukes, 1973]. However, Superior-type sequences in the Animikie Basin and Labrador Trough appear to have been deposited in foreland basins [Hoffman, 1988; Morey and Southwick, 1995]. There are ongoing debates about the environments of deposition of two very large BIFs, the Krivoy Rog and the Minas Supergroup. The Krivoy Rog sequence may have formed in an intercratonic rift [Shchipansky and Bogdanova, 1996], while an active continental margin may have been the environment of deposition of the Minas Supergroup [Castro, 1994]. Consequently, a single paleodepositional model does not fit all Superior-type iron formations. Because so many Superiortype BIFs formed in a shallow marine environment under transgressing seas [Simonson and Hassler, 1996], we can conclude that the process of iron formation deposition must have operated in a variety of paleotectonic and paleodepositional settings.

\section{Compilation of the Geochronology of Banded Iron Formations}

A compilation of geochronological data for 54 BIFs is presented in Table 5. Superior-type sequences include the Hamersley Group, the Transvaal Supergroup, the Minas Supergroup, and deposits in the Labrador Trough-Animikie Basin (the last three listed for the Superior Craton in Table 5). Most of the other sequences contain solely Algoma-type BIFs. A few greenstone belts contain both moderate-size Superiortype BIFs that were deposited in shelf sequences and Algomatype BIFs associated with (ultra)mafic volcanics [James and Trendall, 1982; Eriksson et al., 1994; Card, 1990].

In nine instances the ages of Algoma-type iron formations are constrained by the same geochronologic data as komatiites of the same greenstone belt. In four other greenstone belts containing both komatiites and BIFs, the volcanics and sediments have different age constraints. Other examples of Algoma-type sequences occur in greenstone belts that either do not contain komatiites or do not contain komatiites whose ages have been well constrained.

The ages of Superior-type BIFs are not as well known as those of the Algoma-type BIFs, in part because they do not have the same associations with readily dated volcanogenic rocks. For example, the available data constrain the age of BIF units in the Minas Supergroup within a $\sim 300$-Myr-long period between $\sim 2.7$ and $2.4 \mathrm{Ga}$ (Table 5). The age constraints for BIFs in the Krivoy Rog are similarly poor. However, some workers have assumed that most of the very large Superiortype BIFs were deposited synchronously and advocated an age of $-2.45 \mathrm{Ga}$ for both these sequences [Chemale et al., 1994;
Shchipansky and Bogdanova, 1996], based on the ages of the Brockman and Weeli Wolli Formations (Hamersley Group) and the Ashbeshheuwels Formation (Transvaal Supergroup; see Table 5). We feel this assumption remains unwarranted and have used conservative age ranges based on available geochronologic data (Table 5).

\section{Comparison of the Temporal Records of Mafic Volcanism and BIF Deposition}

\subsection{Derivation of Time Series Data}

Each event in the data set has an age range. If the event can be dated directly, then the age range is the range defined by a single age date. The minimum age is the age minus the published error of the age. The maximum age is the age plus the published error of the age. Because they often contain zirconium-bearing minerals, dike swarms and layered intrusions most often have an age range defined by a single age date.

Iron formations and komatiites are difficult to date directly using high-precision $\mathrm{U} / \mathrm{Pb}$ geochronology. As a result, their age range is most often defined using two ages, the ages of datable horizons that are younger and older than the iron formation or komatiitic layer. The minimum age is defined using the age of the younger horizon minus the published error of the age of the younger horizon. The maximum age is defined using the age of the older horizon plus the published error of the age of the older horizon.

Time series are constructed by using the minimum and maximum age of each event. The data are assumed to have a Gaussian distribution about the mean value of the maximum and minimum ages of each event. Half of the difference between the minimum and maximum ages equals one standard enror about the mean. The total area under each Gaussian is one. The distribution of area is determined by the chosen time increment (1 Myr) and the size of the standard error.

The equation we use to derive the time series, $f(t)$ is

$$
f(t)=\sum_{i=1}^{N} \frac{1}{(2 \pi)^{1 / 2} \sigma_{i}} \exp \left\{\left(t-t_{i}\right)^{2} / 2 \sigma_{i}^{2}\right\}
$$

where $\sigma$ is the standard error of the age date, $t$ is the time in million years, $t_{i}$ is an individual age date, and $N$ is the total number of age dates. The final time series is a sum of many smooth, bell-shaped curves, each one representing one age date and its corresponding error. The result is a smooth time series where the peak heights are a function of two variables: the standard error of each age and the number of ages that overlap.

\subsection{Appearance of Time Series}

We used ages and age errors for each data set to construct a time series for that data. The resulting time series are named for their component data sets: komatiites, dikes and flood basalts, layered intrusions, and iron formation (Figure 1). Each time series extends from 1500 to $4000 \mathrm{Myr}$. Note that there are clear visual correlations of peaks in the iron formation time series with peaks in the other time series.

We also constructed composite time series that are sums of the individual data sets. Because flood basalts plus dikes and layered intrusions are generally confined to continental areas, we combined these two time series to obtain an index of continental plumes. Komatiites can occur in both oceanic and continental settings. Thus we used all three data sets (komatiites, flood basalts plus dikes, and layered intrusions) to obtain an index of the global occurrence of mantle plumes. 
Table 5. Ages and Locations of Iron Formations




Table 5. (continued)

\begin{tabular}{llll}
\hline Craton & \multicolumn{1}{c}{ Location } & \multicolumn{1}{c}{ Age Constraints, Ma } & \multicolumn{1}{c}{ References } \\
\hline Superior & Vulcan Iron Formation & $1910 \pm 10$ and $1852 \pm 6$ & Van Schmus and Bickford [1981] and Sims et al. \\
& & & {$[1989]$} \\
Baltica & Sweden, Bergslagen Supracnustal Sequence & $1890 \pm 30$ and $1860 \pm 30$ & Oen [1987] \\
Superior & Sokoman Iron Formation & $1880 \pm 20$ & Chevé and Machado [1987] \\
Superior & Gunflint Iron Formation & $1879+5.2 /-3.5$ & Wardle et al. [1990] \\
Superior & Biwabik Iron Formation & $1879+5.2 /-3.5$ & Morey and Southwick [1995]
\end{tabular}

- The Negaunee Iron Formation and the Fence River Iron Formations are taken to be contemporaneous with the Vulcan Iron Formation, as suggested by Morey and Southwick [1995].

The Biwabik and Gunflint are taken to be contemporaneous, as suggested by Morey and Southwick [1995].

In Figure 2, peaks in both of these composite time series show a clear visual correlation to peaks in the time series for deposition of iron formation.

\subsection{Cross-Correlation Analysis}

We check the visual correlation between the time series for iron formation and plume proxies by running a detailed crosscorrelation analysis. We use the fully normalized cross correlation that returns a maximum value of unity when the time series are identical and a minimum value of zero when they are very dissimilar. We also assess the statistical significance of our cross correlations between iron formation and plume proxies by comparing them to cross correlations between plume proxies and 1000 randomly generated time series.

The randomly generated time series are derived from 1000 sets of random ages and age errors. The ages and age errors are normalized to the same statistical characteristics as the iron formation ages. That is, the ages have an age range of 1645 to $3817 \mathrm{Ma}$, the age errors have minimum and maximum standard errors of 1.4 and $90 \mathrm{Myr}$, and the number of ages is the same (60). The ages and standard errors are then used to generate a time series (equation (1)) that has the same spectral characteristics as the data.

A cross-correlation analysis of two time series identifies the time offset that makes the two time series most similar. The correlation coefficient quantifies the degree of similarity of the two time series at that time offset. However, because each data set has slightly different spectral characteristics, the significance of a given cross correlation will vary. We test the significance of the cross correlations of plume proxies with iron formation by comparing them to cross correlations between each plume proxy and 1000 randomly generated time series (the Monte Carlo method).

The distribution of correlation coefficients between each plume proxy and 1000 randomly generated time series generally varies between 0.3 and 0.7 (Figure 3). However, some time series produce generally higher correlation coefficients than others. For example, the cross correlations between komatiites and 1000 randomly generated time series have the highest correlation coefficients. In contrast, the

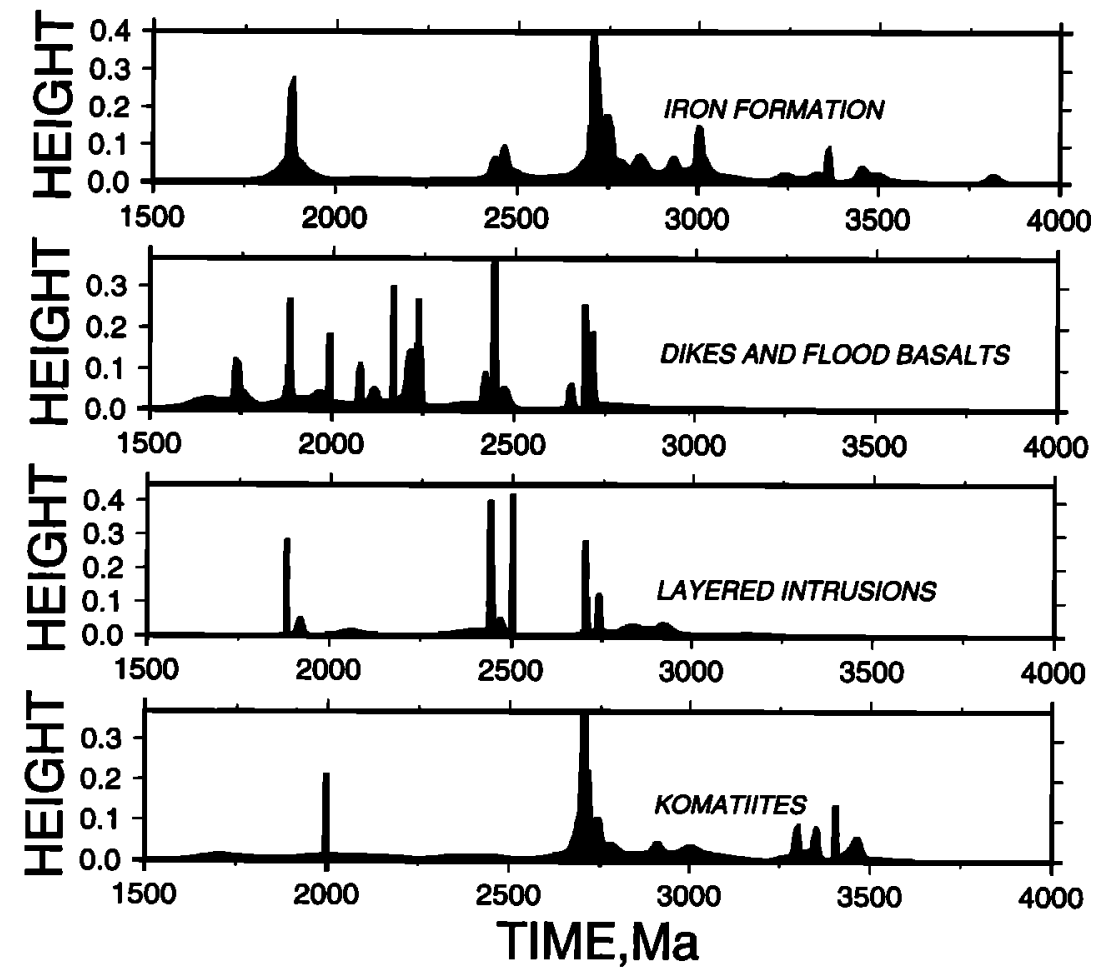

Figure 1. Time series of occurrences of iron formation, dikes and flood basalts, layered intrusions, and komatiites. These time series were generated by summing Gaussian distributions of unit area using the ages and standard deviations in Tables 1-5. Peaks near 2.7,2.45, and $1.9 \mathrm{Ga}$ are apparent in at least three of the four time series shown. 

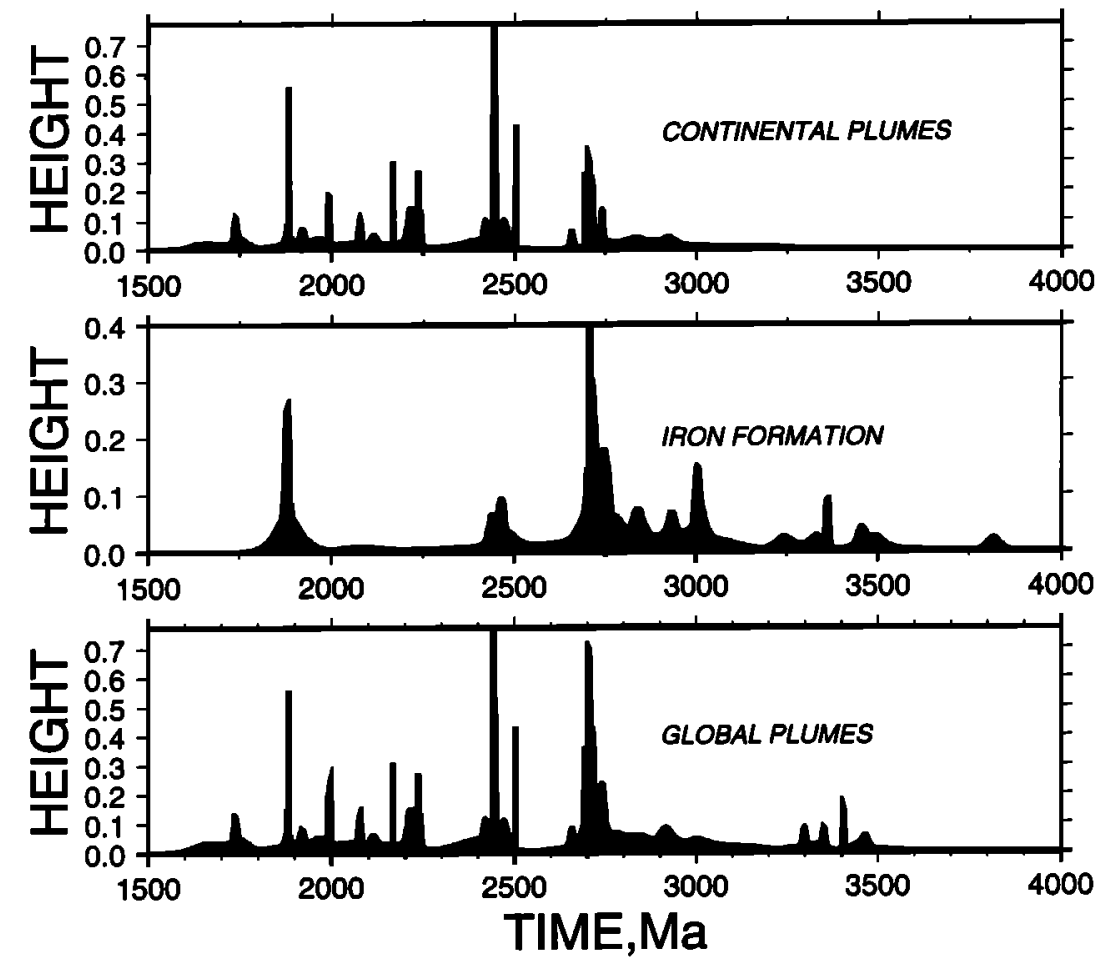

Figure 2. Time series of occurrences of iron formation compared with those of the continental plume time series (derived by summing the results for dikes, flood basalts, and layered intrusions) and of the global plume (derived by summing the continental plume and komatiite time series). These time series were generated by summing the Gaussian distributions of unit area using our compilation of mean ages and standard deviations shown in Tables 1-5. There is an apparent visual correlation between episodes of global and continental mantle plume volcanism and BIF deposition.

cross correlations between layered intrusions and 1000 randomly generated time series have the lowest correlation coefficients. As a result, a correlation value of 0.582 is needed to generate a $99 \%$ confidence level in the cross correlation between layered intrusions and another time series (Table 6). For komatiites a much higher correlation value of 0.712 is needed for a $99 \%$ confidence level in a cross correlation between komatiites and another lime series. Therefore the statistical significance (i.e., confidence level) of a given correlation coefficient must be evaluated individually for each cross correlation of iron formation with plume proxies.

We also use a Monte Carlo method to estimate the confidence intervals for the lag times. We assume that errors in the estimates of the lag times arise solely from errors in the age dating, as quantified by the published age date confidence intervals. The ability of the cross-correlation technique to determine lag time is then a function of the number of age dates in each pair of time series, and the distribution of variances of these age dates. Monte Carlo simulations indicate that the standard enror of the time lag decreases approximately with the square root of the number of age dates, with smallest age date variance controlling the size of the time lag variance. The distributions of age date confidence limits for the various types of plume proxies are all rather similar and roughly obey an exponential distribution with an expectation of about 15 Myr. Simulations based on this distribution indicate that the 95\% confidence limits for lag times do not exceed 3 Myr for the time series considered in this paper.

The cross-correlation analyses between plume proxies and iron formation show that the komatiite, global plume, and continental plume results have correlation coefficients that are significant at the $99 \%$ confidence level (Table 6 and Figure 4).
The komatiites and global plumes have very small lag times of 3 and $2 \mathrm{Myr}$, respectively. The continental plumes have a time lag of $\mathbf{2 6 4}$ Myr. However, there is a strong secondary peak at a time lag of 1 Myr. This secondary peak has a confidence level of $85 \%$.

The cross-correlation results for the dikes plus flood basalts and the layered intrusions are not as strong. Both of these cross correlations gave best fit time lags of $264 \mathrm{Myr}$. The correlation coefficient of the cross correlation between iron formation and dikes plus flood basalts is significant at the $83 \%$ confidence level (Table 6 and Figure 4). The correlation coefficient of the cross correlation between iron formation and layered intrusions is significant at the $96 \%$ confidence level. Both of these latter cross correlations have strong secondary peaks with time lags of $3 \mathrm{Myr}$. The secondary peak from the cross correlation between iron formations and layered intrusions is significant at the $94 \%$ confidence level. The secondary peak from the cross correlation between iron formation and dikes plus flood basalts is significant only at the $21 \%$ level.

\section{Discussion}

\subsection{Our Interpretation of Cross-Correlation Analyses}

We believe these cross-correlation analyses confirm the temporal coincidence between BIF deposition and mantle plume volcanism in both continental and oceanic environments. First, as expressed by the confidence level of correlation coefficients, both of the pooled time series (global and continental plumes), and the komatiite time series, are more strongly correlated with BIF deposition than virtually all 

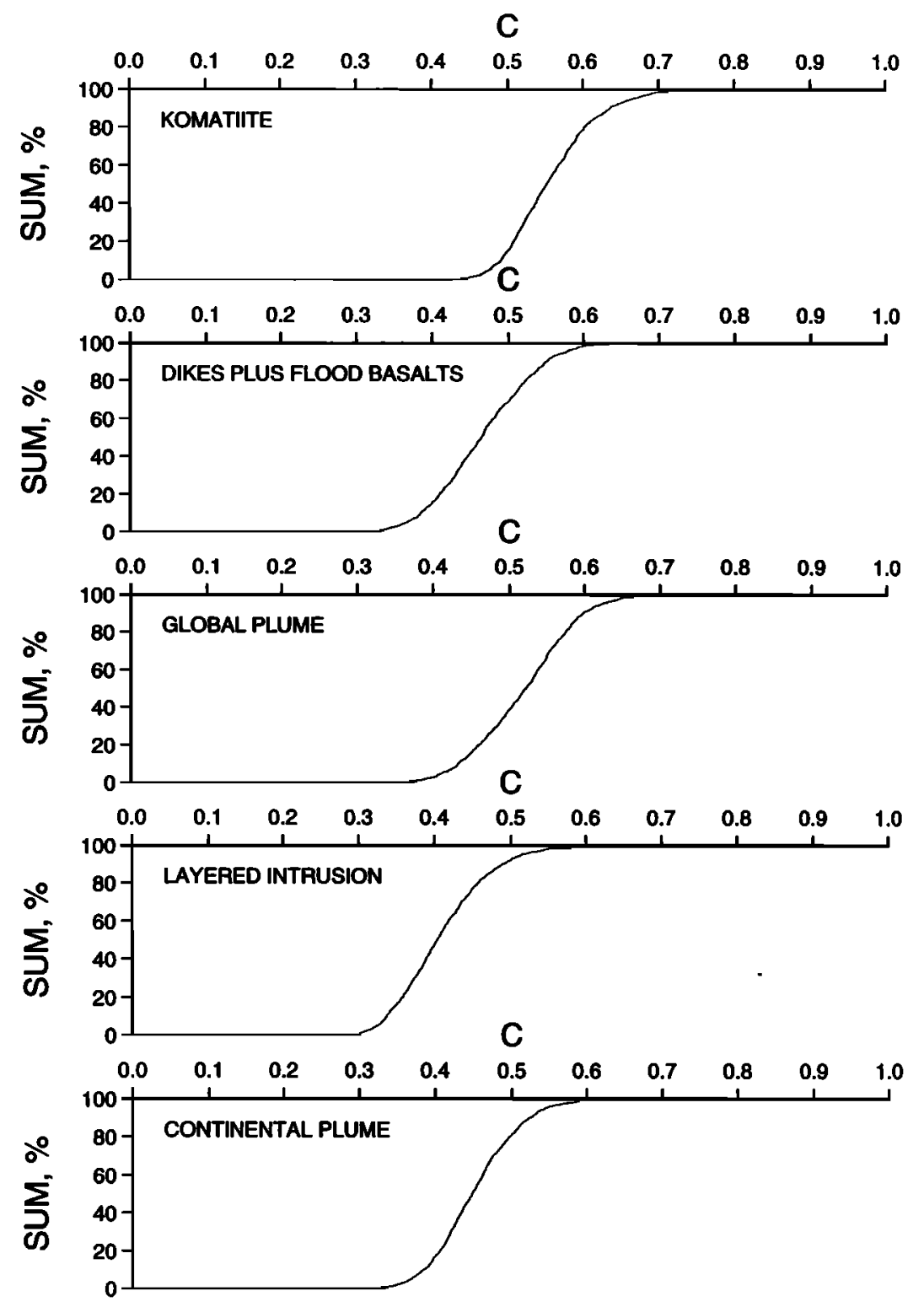

Figure 3. Correlation coefficient $(C)$ versus percentage of correlation coefficients that are smaller (SUM, \%). The percentage of correlation coefficients that are smaller is roughly the confidence level of that correlation coefficient. Because each time series has differing spectral characteristics, each time series has slightly different confidence levels for the same correlation coefficient. Plots show the ranges in the correlation coefficients derived from 1000 cross correlations of each time series (komatiites, dikes plus flood basalts, global plume, layered intrusions, and continental plume) with 1000 randomly generated time series.

of the randomly generated time series. Further, as noted above, peaks in all but the komatiite time series occur approximately every $200-300 \mathrm{My}$ between about 2.75 and $1.9 \mathrm{Ga}$ (Figure 1).

When examined separately, the flood basalt/dike and layered intrusion time series have relatively weak correlations with the deposition of iron formation (Table 6 and Figure 4) The largest peak for both cross correlations occurs at a time lag of 264 Myr. Both cross correlations have secondary peaks at time lags of $3 \mathrm{Myr}$. The confidence level of the secondary peak for layered intrusions is high, $295 \%$. However, the confidence level of the secondary peak for dikes plus flood basalts is very low, only $21 \%$. When the data sets are pooled, the confidence level of the secondary peak at a time lag of $1 \mathrm{Myr}$ is intermediate, $\sim 85 \%$.

Although the confidence level for the cross correlation of iron formation with continental plumes is relatively low
(85\%), we believe that the higher confidence level for ultramafic layered intrusions is significant. Ultramafic layered intrusions are almost always associated with mantle plume activity. In contrast, dike swarms may form during abortive rifting that is not necessarily plume related. Thus the 95\% confidence level of the secondary peak in the cross correlation between iron formation and layered intrusions supports a temporal correlation between continental plume activity and the deposition of iron formation.

In summary, we interpret the maximum and secondary time lags with over $84 \%$ confidence level as expressing two types of geological events. The 1 to 3 Myr time lags represent the time between mantle plume activity and the deposition of iron formation. The 264 Myr time lags may represent the average time interval between mantle superplume events from 3.8 to $1.6 \mathrm{Ga}$. This latter conclusion must be further tested with a 
Table 6. Comparison of Results of Cross Correlations of Iron Formation to Plume Proxies and to 1000 Random Time Series With Similar Spectral Characteristics

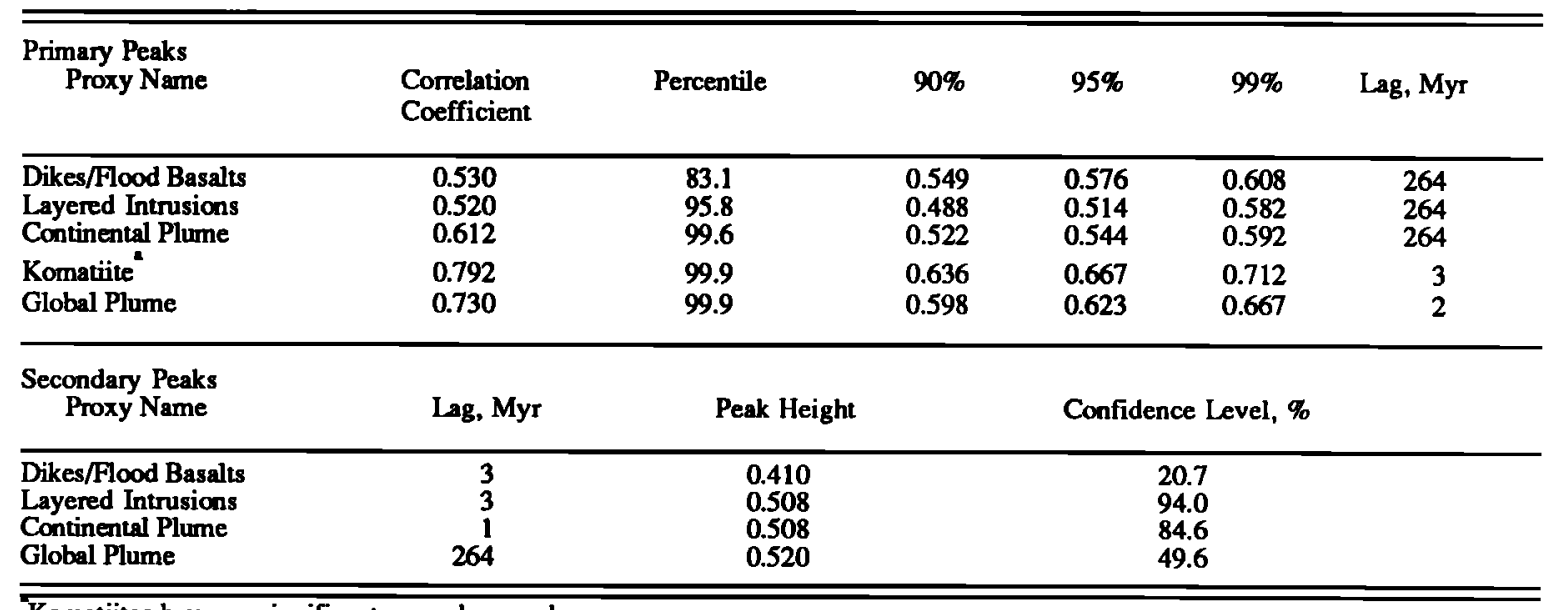

Komatiites have no significant secondary peaks.

spectral analysis and a longer time series that are outside the scope of this paper.

\subsection{Superplume Events}

Therefore the data compiled here show that the temporal correlation between the time of deposition of Archean and Paleoproterozoic BIFs and the eruption of plume-derived mafic volcanism is statistically significant. Our analyses show that four periods between 3.8 and $1.6 \mathrm{Ga}$ were characterized by mantle (super)plume events. At least three of these periods also had significantly enhanced accumulation rates of BIF.

10.3. The 2.75-2.70 Ga Mantle Superplume Event and Deposition of BIF

In this portion of the geologic record, temporal distributions of all proxies for mantle plume activity have maxima. Flood basalts and numerous komatiitic sequences of this age have previously been attributed to mantle plume activity [Kusky and Kidd, 1992; Blake, 1993; Desrochers et al., 1993; Amelin et al., 1995; Skulski and Percival, 1996; Dostal and Mueller, 1997; Puchtel et al., 1997a]. In fact, while the komatiite maximum occurs here as a single broad peak, two distinct peaks occur in the continental record (dike swarms and layered intrusions): one centered near $2.75 \mathrm{Ga}$ and one near $2.70 \mathrm{Ga}$ (Figure 1). A $-2.7 \mathrm{Ga}$ marine transgression is recorded in the Pilbara craton's sequence stratigraphy, and the volcanic sequences erupted there during the period 2.8-2.7 Ga support two mantle plume events [Blake, 1993]. Perhaps two mantle plumes were active during this time, separated by $50 \mathrm{Myr}$. Conversely, these data may indicate that there was a single mantle plume, initially centered under rifting continental lithosphere, and $50 \mathrm{Myr}$ later, affecting both continental and oceanic realms. Such a feature has an analogue in the Mesozoic to modern central Atlantic plume, a long-lived event that promoted Triassic rifting and formation of the Atlantic Ocean and that has been associated with Tertiary-Quatemary volcanism in a belt from the Cape Verde Islands through western Europe [Oyarzun et al., 1997]. Regardless of the number of active plumes in this $50 \mathrm{Myr}$ interval, the Pilbara, Baltic, Superior, Kaapvaal, Yilgam, and Wyoming Cratons were affected by plume volcanism (Tables 1-4). These data support the existence of a mantle superplume event (on the scale of the mid-Cretaceous Pacific plume) between 2.75 and $2.70 \mathrm{Ga}$.
Approximately $25 \%$ of the dated BIFs were deposited during this time period, which represents only about $2 \%$ of the geologic record examined here. These BIFs comprise a wide range of chemistries and mineralogies, with sulfide through oxide facies represented. Several of the Algoma-containing sequences have been interpreted as accreted ocean plateaus [Kusky and Kidd, 1992; Desrochers et al., 1993; Skulski and Percival, 1996]. Other BIFs deposited during this time, for example, the Boston, Helen, El Dorado, Chambers-Briggs, and Bartlett iron formations in the Abitibi Greenstone Belt, are associated with (ultra)mafic through felsic volcanics but have thicknesses exceeding $500 \mathrm{~m}$, more comparable to those of Superior-type BIFs [Card, 1990; Blum and Crockett, 1992; Jackson et al., 1994]. It is unclear whether these are autochthonous or allochthonous sequences and unclear whether these assemblages are related to oceanic plume volcanism or were deposited in rift environments [Jackson et al., 1994]. Given the uncertainties in their ages, it is possible that Superior-type BIFs in the Carajas, Cauê, Marra Mamba and Wanderer Formations also were deposited during this interval (Table 5) [Tsomondo et al., 1992]. If so, as much as $20 \%$ of the total volume of BIF may have formed in this $50 \mathrm{Myr}$ period [James and Trendall, 1982].

\subsection{The 2.50-2.40 Ga Mantle Superplume Event and Deposition of BIF}

A second group of peaks occurs in the dike swarm and mafic layered intrusion series between 2.5 and $2.4 \mathrm{Ga}$. Only one sequence of komatiitic lavas are known from this time, and it occurs in the Strelna Group [Puchtel et al., 1991], one of the two large coeval flood basalt sequences erupted on Baltica (Table 2). The global character of volcanism during this period and the size of continental mafic provinces $\left(>1.5 \times 10^{3} \mathrm{~km}^{2}\right)$ indicate that there was a subcontinental mantle superplume event centered at $\sim 2.44 \mathrm{Ga}$ [Heaman, 1997]. We are not aware of 2.5-2.4 Ga accreted oceanic plateaus or seamounts. Nonetheless, a coeval marine transgression [Simonson and Hassler, 1996] suggests that this mantle superplume also produced great volumes of ocean crust.

The 2.5-2.4 Ga period represents $\sim 4 \%$ of the geologic record examined here. That $11 \%$ of the BIFs listed in Table 5 were deposited in this interval indicates unusually high BIF accumulation rates per unit time. This fact is underscored by considering the volume of BIF deposited. Portions of the Hamersley Group and Transvaal Supergroup were accumulating, 

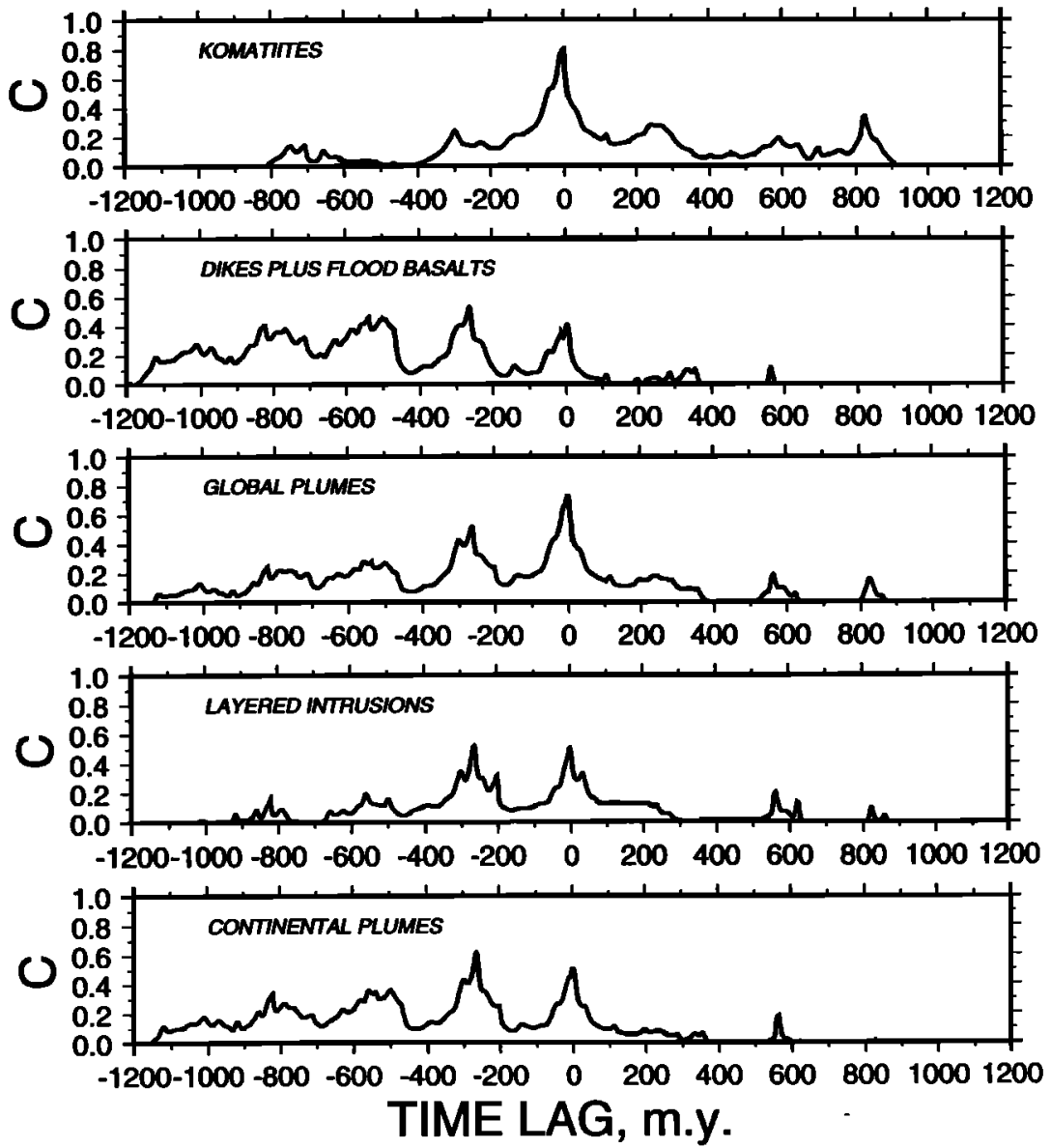

Figure 4. Correlation coefficient $(C)$ versus time lag in million years for individual cross correlations between time series of plume proxies (komatiites, dikes plus flood basalts, global plume, layered intrusions, and continental plume) and iron formation. The highest peak represents the time lag at which the two time series are most similar.

and it is possible that the Minas Supergroup and BIFs deposited in the Krivoy Rog and Kursk Supergroups were coeval deposits [Chemale et al., 1994; Shchipansky and Bogdanova, 1996]. Perhaps as much as $40 \%$ of the global volume of BIF accumulated in the Hamersley and Transvaal Basins; if deposition of the very large Brazilian and Ukranian BIFs occurred concurrently, then perhaps as much as $60 \%$ of all BIF was deposited during this time [James and Trendall, 1982]. Deposition of BIF was confined to shallow marine environments, including the continental shelves of passive tectonic margins and intracratonic rifts.

\subsection{The 2.25-2.20 Ga Mantle Plume Event and Deposition of BIF}

On the basis of the distribution of dike swarms of this age on the Slave and Superior cratons [Buchan et al., 1996; LeCheminant et al., 1996], it was proposed that a mantle plume event occurred between 2.25 and $2.1 \mathrm{Ga}$. In the data set presented here, the evidence for this event occurs mainly in the dike record and is constrained to a narrower time interval (2.25-2.20 Ga, Figure 1). Mafic dikes of this age are known not only from the Slave and Superior Cratons, but also from the Dharwar, Nain, and Antarctic areas (Table 3). Guyanese komatiites may be of this age (Table 1). Like South America [Goldstein et al., 1997], much of West Africa was accreted between 2.2 and $2.1 \mathrm{Ga}$ [Boher et al., 1992]. Abouchami et al. [1990] interpreted the $10-\mathrm{km}$-thick Birimian Mako volcanics (dominantly tholeiitic basalts with an age of $2195 \pm 118 \mathrm{Ma}$ ) as a flood basalt sequence with a mantle plume source, but they could not distinguish whether these were continental or oceanic flood basalts. On the basis of these data, we concur with others who have proposed a mantle plume event at this time and suggest that it influenced both continental and marine environments.

The upper age limits of BIFs in the Transvaal Supergroup overlap with this period (Table 5). Furthermore, there are numerous iron formations whose current age constraints indicate they might be of this age: in the Kalahari manganese field, in Australia's Naberru Basin and Middleback Range, the Ijil Group (Mauritania), the Paramaca Formation (Saõ Francisco craton), the Gorumahisani BIF (India) and in the Bohemian Massif [James and Trendall, 1982; Walker et al., 1983; Banerji, 1984; Pouba and Kríbek, 1986; Tyler and Thorne, 1990; Cornell and Schütte, 1995]. Together these represent between 5 and $15 \%$ of the total volume of BIF deposited globally [James and Trendall, 1982]. These BIFs are either moderate to large class Superior-type deposits, or else they are unusually thick Algoma-type units associated with bimodal (mafic-felsic) volcanics. Given the uncertainties in their ages at the present time, it is impossible to say if these BIFs were deposited coevally during the period $2.25-2.20 \mathrm{Ga}$, but the possibility cannot be ruled out. 
10.6. The 2.0-1.86 Ga Mantle Plume Event and Deposition of BIF

All proxies of continental mantle plume activity suggest an event between 2.0 and $1.86 \mathrm{Ga}$ (Figure 1), associated with rocks in the Trans-Hudson and New Quebec (Penokean) orogenic belts [Hoffman, 1988; Sims et al., 1993]. The $~ 1.99$ $1.95 \mathrm{Ga}$ komatiitic basalts and tholeiites of the Povungnituk Group erupted during :ifting of the Superior craton, and a hot spot (mantle plume) inay have promoted eruption of that $5-\mathrm{km}$ thick volcanic sequence [Hynes and Francis, 1982; St. Onge et al., 1992]. Similarly, the $1.91 \mathrm{Ga}$ Hemlock Formation records a later phase of continental rifting [Van Schmus and Bickford, 1981]. The Katiniq sills, layered intrusions of quartz ferrogabbros, are -1.92 By old [Parrish, 1989]. The $1.88 \mathrm{Ga}$ Fox River sill in the Cape Smith foldbelt is a layered intrusion with a komatiitic geochemistry [Heaman et al., 1986]. During the Ungava, Penokean, and Trans-Hudson orogens, oceanic crust was accreted during the collisional phase [Lucas and $S t$. Onge, 1992; Sims et al., 1993]. For example, the Watts Group's Purtuniq ophiolite, accreted during the Ongava orogen, is $1998 \pm 2$ Ma old and contains ultramafic cumulates, sheeted dikes and pillow basalts [Parrish, 1989; St. Onge et al., 1992]. In the Quinnesec Formation (Penokean orogen), $\sim 1.87 \mathrm{Ga}$ tholeiitic basalts comprise a dismembered ophiolite [Sims et al., 1993].

Other regions record (ultra)mafic volcanism at this time. Baltica's Onega Plateau, a 4.5-km-thick volcanic sequence covering $6 \times 10^{6} \mathrm{~km}^{2}$, erupted at $\sim 1.98 \mathrm{Ga}$ (Table 2). It formed by mantle plume activity [Fuchtel et al., 1999]. Ultramafic dike swarms on the Kaapvaal, Lewisian, Baltic, Superior and Indian cratons were emplaced between $\sim 2.0$ and $1.88 \mathrm{Ga}$ (Table 3). Komatiites that may be of this age erupted in Baltica and Amazonia (Table 1).

During this time the very large BIFs of the Labrador Trough and Animikie Basin accumulated (Table 5). These may contain up to $15 \%$ of the total global BIF volume [James and Trendall, 1982]. Not all of the iron formations in these basins are "Superior-type," although this is the location where that class of BIF was first described. Algoma-type BIFs in the region (Negaunee, Fence River, and Vulcan iron formations) were deposited in fault-bounded half-grabens dissecting a shelf [Morey and Southwick, 1995]. The Superior-type sequences, including the Gunflint and Biwabik iron formations of the Animikie Group, accumulated on passive margins that evolved into foredeep basins during the collision of the Wisconsin magmatic terranes [Morey and Southwick, 1995]. They were deposited during a marine transgression [Simonson and Hassler, 1996]. The Sokoman iron formation of the Labrador Trough also accumulated in a foredeep basin during a marine transgression [Hoffman, 1988; Simonson and Hassler, 1996].

\subsection{Why Is There a Correlation Between Mantle Plumes and BIF Deposition?}

There is a strong correlation between the eruption of plumegenerated magmas and the deposition of banded iron formation. We believe that there are a number of ways in which plume-related magmatism could enhance the accumulation rate of BIF. Perhaps most obviously, mantle plume volcanism may have served as the source of Fe to BIFs, regardless of whether the plume was situated beneath continental or oceanic lithosphere. Mantle plumes also produce volcanic edifices (primarily oceanic), and extensional basins (primarily continental), with proximal hydrothermal effluent debouching sites. These paleotectonic environments are likely to survive in the geologic record. Displacement of marine waters by ocean crust formed from magmas enupted during mantle plume events could account for deposition of Superior-type BIFs under transgressing seas. During the Archean and Paleoproterozoic, high-temperature weathering of basalts could have removed substantial amounts of $\mathrm{O}_{2}$ from the atmosphere-ocean system, increasing the likelihood of longdistance marine transport of dissolved ferrous Fe. Finally, the efficacy of hydrothermal plumes as an agent of Fe transport to continental shelves depends not only on $\mathrm{pO}_{2}$ in the atmosphere-ocean system but also on their depth. Hydrothermal plumes originating at seamounts and oceanic plateaus are introduced directly into the shallow to intermediate water column [Karl et al., 1988; Cheminée et al., 1991; Lupton, 1996]. As we previously discussed, recent research on the behavior of plumes of hydrothermal effluent in the marine water column shows that they rise to a depth of neutral buoyancy and then spread outward. If the depth of neutral buoyancy is shallower than the depth of the continental shelf, the plumes will spread through the water column above the continental shelf and material from the plume will be deposited in shelf sediments. We suggest that during these mantle plume events a global $\mathrm{O}_{2}$ minimum-Fe maximum developed in the upper oceans, explaining the accumulation of Algoma- and Superior-type BIFs in a variety of paleodepositional environments.

\section{Conclusions}

This work shows a strong temporal correlation between the deposition of Superior- and Algoma-type banded iron formation and episodes of mafic mantle plume magmatism. This mafic mantle plume magmatism was expressed on continents as flood basalts, massive dike swarms, and layered intrusions. Within the ocean basins the mantle plume magmatism was manifested as komatiitic volcanics interbedded with more voluminous, high-iron basalts. Many Algoma-type sequences formed on ocean plateaus or seamounts, intercalated with such volcanics, and therefore had a proximal hydrothermal source. We suggest that other BIFs were deposited from hydrothermal plumes transporting water particularly rich in $\mathrm{Fe}$ and poor in $\mathrm{O}_{2}$ during periods of oceancentered mantle plume volcanism.

Acknowledgements. We thank Mary Anne Brueckner for her assistance obtaining the published and unpublished data sets utilized here. We thank Sarah Hoffman for editing. We particularly thank Nicolas Beukes, Bruce Simonson, and Tim Lutz, whose reviews were a great help.

\section{References}

Abbott, D., and W. Mooney, The structural and geochemical evolution of the continental crust: Support for the oceanic plateau model of continental growh, US. Nall. Rep. Int. Union Geod. Geophys. 1991 . 1994, Rev. Geophys., Suppl., 33, 231-242, 1995.

Abbout, D., L. Burgess, J. Longhi, and W. H. F. Smith , An empirical thermal history of the Earth's upper mantle, J. Geophys. Res., 99, 13,835-18,850, 1994.

Abouchami, W., M. Boher, A. Michard, and F. Albarede, A major 2.1 Ga event of mafic magmatism in West Africa: An earty stage of crustal accretion, J. Geophys. Res., 95, 17,605-17,629, 1990.

Alibert, $\mathrm{C}$, and M. T. McCulloch, Rare earth element and neodymium composition of the banded iron formations and associated shales from Hamersley, Westem Australia, Geochim. Cosmochim. Acta, 57, 187-204, 1993.

Allen, R. L. I Lundstrōm, M. Ripa, A. Simeonov, and H. Christofferson, Facies analysis of a $1.9 \mathrm{Ga}$ continental margin, back-arc, felsic caldera province with diverse $\mathrm{Zn}-\mathrm{Pb}-\mathrm{Ag}-(\mathrm{Cu}-\mathrm{Au})$ sulfide and $\mathrm{Fe}$ oxide deposits, Bergslagen region, Sweden, Econ. Geol., 91, 979$1008,1996$.

Amelin, Y. V., L. M. Heaman, and V. S. Semenov, U-Pb geochronology of layered mafic intrusions in the eastern Baltic Shield: Implications for the timing and duration of Paleoproterozoic continental rifting, Precambrian Res., 75, 31-46, 1995. 
Appel, P. W. U., On the Early Archaean Isua iron-formation, west Greenland, Precambrian Res., 11, 73-87, 1980.

Armstrong, R. A., Geochronological studies on Archaean and Proterozoic formations of the foreland of the Namaqualand Front and possible correlations on the Kaapvaal Craton, doctoral dissertation, 274 pp. Univ. Witwatersrand, Johannesburg, 1987.

Amstrong, R. A., W. Compston, M. J. deWit, and I. S. Williams, The stratigraphy of the 3.5-3.2 Ga Barberton greenstone belt revisited: A single zircon ion microprobe study, Earth Planet. Sci. Lett., 101, 90$106,1990$.

Armstrong, R. A., W. Compston, E. A. Retief, I. S. Williams, and H. J. Welks, Zircon ion microprobe studies bearing on the age and evolution of the Witwatersrand triad, Precambian Res., 53, 243$266,1991$.

Amdt, N. T., and W. Todt, Formation of 1.9-Ga-old Trans-Hudson continental crust: $\mathrm{Pb}$ isotopic data, Chem. Geol. 118, 9-26, 1994.

Amdt, N. T., D. R. Nelson, W. Compston, A. F. Trendall, and A. M. Thome, The age of the Fortescue Group, Hamersley Basin, Westem Australia, from ion microprobe zircon U-Pb results, Aust. J. Earth Sci., 38, 261-281, 1991.

Ashwal, L. D., S. B. Jacobsen, J. S. Myers, and F. Kalsbeek, Sm-Nd age of the Archean Fiskanaesset anorthosite complex, west Greenland (abstract), Eos Trans. AGU, 67, 1263-1264, 1986.

Baadsgaard, H., A. P. Nutman, D. Bridgewater, M. T.Rosing, V. M. McGregor, and J. H. Allaart, The zircon geochronology of the Akilia association and Isua supracrustal belt, west Greenland, Earth Planet. Sci. Lett. 68, 221-228, 1984.

Babinski, M., F. Chemale Jr., and W. R. Van Schmus, The $\mathrm{Pb} / \mathrm{Pb}$ age of the Minas Supergroup carbonate rocks, Quadrilátero Ferrifero, Brazil, Precambrian Res., 72, 235-245, 1995.

Baker, E. T., and G. Massoth, Characteristics of two hydrothermal plumes from two vent fields on the Juan de Fuca Ridge, northeast Pacific Ocean, Earth Planet. Sci. Lett., 85, 59-73, 1987.

Balashov, Y. A., T. B. Bayanova, and F. P. Mitrofanov, Isotope data on the age and genesis of layered basic-ultrabasic intrusions in the Kola Peninsula and northem Karelia, northeastem Baltic Shield, Precambrian Res., 64, 197-205, 1993.

Balasubrahmanyan, M. N., The age of dykes of south Kanara, Mysore State, Geol. Surv. India Misc. Pubi., 23, 236-239, 1975.

Banerji, P. K., On some geochemical features of the vanadiferous magnetite deposits of Kumhardubi and Betjharan, Mayurbhanj District, Orissa, India, Chem. Geol., 43, 257-269, 1984.

Barley, M. E., A. L. Pickard, and P. J. Sylvester, Emplacement of a large igneous province as a possible cause of banded iron formation 2.45 billion years ago, Nalure, 385, 55-58, 1997.

Barrie, C. T., and D. W. Davis, Timing of magmatism and deformation in the Kamiskotia-Kidd Creek area, westem Abitibi Subprovince, Canada, Precambrian Res., 46, 217-240, 1990.

Barton, J. M., Jr., The Mugford group volcanics of Labrador: Age, geochemistry, and tectonic setting, Can. J. Earth Sci., 12, 1196-1208, 1975.

Barton, J.M., Jr., R. E. P. Fripp, P. Horrocks, and N. McLean, The geology, age, and tectonic setting of the Messina Layered Intrusion, Limpopo Mobile Belt, southem Africa, Am. J. Sci., 279, 1108-1134, 1979.

Barton, J. M., Jr., R. E. P. Fripp, and R. C. Horrocks, Rb-Sr ages and chemical composition of some deformed Archaean mafic dykes, central zone, Limpopo Mobile Belt, southem Africa, Spec. Publ. Geol. Soc. S. Africa, 8, 27-37, 1983

Bau, M., and P. Möller, Rare earth element systematics of the chemically precipitated component in Early Precambrian iron formations and the evolution of the terrestrial atmospherehydrosphere-lithosphere system, Geochim. Cosmochim. Acta, 57, 2239-2249, 1993.

Ben-Avraham, Z, A. Nur, D. Jones, and A. Cox, Continental accretion: From oceanic plateaus to allochthonous terranes, Science, 213, 4754,1981 .

Beukes, N. J., Precambrian iron-formations of southem Africa. Econ. Geol., 68, 960-1024, 1973.

Beukes, N. J., Paleoenvironmental setting of the iron-formations in the depositional basin of the Transvaal Supergroup, South Africa, IronFormation: Facts and Problems, edited by A. F. Trendall and R. C Morris, pp. 131-209, Elsevier, New York, 1983.

Biao, S., A. P. Nutman, L. Dunyi, and W. Jiashan, 3800 to $2500 \mathrm{Ma}$ crustal evolution in the Anshan area of Lianoing Province, northeastem China, Precambrian Res., 78, 79-94, 1996.

Bickford, M. E., R. D. Shuster, and S. J. Boandman, U-Pb geochronology of the Proterozoic volcano-plutonic terrane in the Gunnison and Salida areas, Colorado, Spec. Pap. Geol. Soc. Am., 235, 33-48, 1989.

Bickle, M. J., L. F. Bettenay, H. J. Chapman, D. I. Grooves, N. J. McNaughton, I. H. Campbell, and J. R. de Laeter, The age and origin of younger granitic plutons of the Shaw Batholith in the Archean Pilbara Block, Contrib. Mineral. Petrol., 101, 361-376, 1989.

Blake, T. S., Late Archean crustal extension, flood basalt volcanism and continental rifting: The Nullagine and Mount Jope Supersequences, Western Australia, Precambrian Res., 60, 185-242, 1993.

Blake, T. S. and D. I. Grooves, Continental rifting and the ArcheanProterozoic transition, Geology, 15, 229-232, 1987.

Blum, N., and J. H. Crocket, Repetitive cyclical volcanism in the Late Archean Larder Lake Group near Kitkland Lake, Ontario: Implications of geochemistry on magma genesis, Precambrian Res., $54,173-194,1992$.

Boher, M., W. Abouchami, A. Michard, F. Albarde, and N. T. Amdt, Crustal growth in West Africa at 2.1 Ga, J. Geophys. Res., 97, 345369, 1992.

Boulter, C. A., M. J. Bickle, B. Gibson, and R. K. Wright, Horizontal tectonics pre-dating upper Gorge Creek Group sedimentation, Pilbara Block, Westem Australia, Precambrian Res., 36, 241-258, 1987.

Brügmann, G. E., and A. J. N. Naldrett, Platinum-group element abundances in mafic and ultramafic rocks, Ont. Geol. Surv. Misc. Pap., 136, 99-114, 1987.

Buchan, K. L. J. K. Mortensen, and K. D. Card, Northeast-trending Early Proterozoic dykes of the southem Superior Province: Multiple episodes of emplacement recognized from integrated paleomagnetism and U-Pb geochronology, Can. J. Earth Sci., 30, 1286-1296, 1993.

Buchan, K. L., H. C. Halls, and J. K. Mortensen, Paleomagnetism, U-Pb geochronology, and geochemistry of Marathon dykes, Superior Province, and comparison with the Fort Frances swarm, Can.J. Earth Sci., 33, 1538-1595, 1996.

Buick, R., J. R. Thomett, N. J. McNaughton, J.B. Smith, M.E. Barley, and M. Savage, Record of emergent continental crust 3.5 billion years ago in the Pilbara Craton of Australia, Nature, 375, 574-577, 1995.

Burger, A. J., and F. J. Coertze, Radiometric age measurements on rocks from southem Africa to the end of 1971, Bull. 58,46 Pp., Geol. Surv. S. Afr., Pretoria, 1973.

Burger, A. J., and F. J. Coertze, Summary of age determinations carried out during the period April 1974 to March 1975, Annals of the Geol. Surv., Pretoria, 11, 317-321, 1976

Byerly, G. R., A. Kröner, D. R. Lowe, W. Todt, and M. W. Walsh, Prolonged magmatism and time constraints for sediment deposition in the Early Archean Barberton Greenstone Belt: Evidence from the Upper Onverwacht and Fig Tree Groups, Precambrian Res., 78, 125-138, 1996.

Cadman, A. C., L. Heaman, J. Tamey, R. Wardle, and T. E. Krogh, U. $\mathrm{Pb}$ geochronology and geochemical variation within two Proterozoic mafic dyke swarms, Canada, Can. J. Earth Sci., 30, 1490-1504, 1993.

Campbell, I. H., and R. W. Griffiths, Implications of mantle plume structure for the evolution of flood basalts, Earth Planet. Sci. Lett., 99, 79-93, 1990.

Campbell, I. H., and R. W. Griffiths, The changing nature of mantle hotspots through time: Implications for the chemical evolution of the mantle, J. Geol., 92, 497-523, 1992.

Campbell, I. H., and R. I. Hill, A two-stage model for the formation of the granite-greenstone terrains of the Kalgoorlie-Norseman area, western Australia, Earth Planet. Sci. Lett., 90, 11-25, 1988.

Campbell, I. H., R. W. Griffiths, and R.I. Hill, Melting in an Archean mantle plume: Heads it's basalts, tails it's komatiites, Nature, 339, 697-699, 1989.

Card, K. D., A review of the Superior Province of the Canadian Shield, a product of Archean accretion, Precambrian Res., 48, 99-156, 1990.

Castro, L. O., Genesis of banded iron-formations, Econ. Geol., 89, 1384$1397,1994$.

Chemale, F., Jr., C. A. Rosière, and I. Endo, The tectonic evolution of the Quadrilátero Ferrífero, Minas Gerais, Brazil, Precambrian Res., 65, 25-54, 1994.

Cheminée, J.-L., P. Stoffers, G. McMurtry, H. Richnow, D. Puteanus, and P. Sedwick, Gas-rich submarine exhalations during the 1989 eruption of Macdonald Seamount, Earth Planet. Sci. Lett., 107, 318327, 1991.

Cheney, E. S., and $\mathrm{H}$. de la R. Winter, The Late Archean to Mesoproterozoic major unconformity-bounded units of the Kaapvaal Province of southem Africa, Precambrian Res., 74, 203223, 1995.

Cheve, S. R., and N. Machado, Reinvestigation of the Castigon Lake carbonale complex, Labrador Trough, new Quebec, Geol. Assoc. Can. Abstr. Programs, 13, 20, 1988.

Claoue-Long, J. C., W. Compston, and A. Cowden, The age of the Kambalda greenstones resolved by ion-microprobe: Implications for Archaean dating methods, Earth Planet. Sci. Lett., 89, 239-259, 1988.

Compston, W., I. S. Williarns, M. T. McCullough, J. J. Foster, P. A. Arriens, and A. F. Trendall, A revised age for the Hamersley Group, paper presented at Geol. Soc. of Aust., 5th Annual Convention, Perth, 1981.

Condie, K. C., Archean Greenstone Belts, Amsterdam, Elsevier, 442 pp, 1981. 
Corfu, F., The evolution of the southem Abitibi Greenstone Belt in light of precise U-Pb geochronology, Econ. Geol., 88, 1323-1340, 1993.

Corfu, F., and T. L. Muir, The Hemlo-Heron Bay Greenstone Belt and Hemlo Au-Mo deposit, Chem. Geol., 79, 201-223, 1989.

Corfu, F., and S. R. Noble, Genesis of the southem Abitibi Greenstone Belt, Superior Province, Canada: Evidence from zircon Hf isotope analysis using a single filament technique, Geochim. Cosmochim. Acta, 56, 2081-2097, 1992.

Corfu, F., and G. M. Stot, U-Pb ages for late magmatism and regional deformation in the Shebandowan Belt, Superior Province, Canada, Can. J. Earth Sci., 23, 1075-1082, 1986.

Corfu, F., and G. M. Stott, U-Pb geochronology of the central Uchi Subprovince, Superior Province, Can. J. Earth Sci., 30, 1179-1196, 1993.

Corfu, F., and $\mathrm{H}$. Wallace, U-Pb zircon ages for magmatism in the Red Lake greenstone belt, northwestern Ontario, Can. J. Earth Sci., 23 . $27-42,1986$

Corfu, F., and J. Wood, U-Pb zircon ages in supracrustal and plutonic rocks, North Spirit Lake area, northwestem Ontario, Can. J. Earth Sci., 23, 967-977, 1986.

Corfu, F., T. E. Krogh, Y. Y. Kwok, and L. S. Jensen, U-Pb zircon geochronology in the southwestern Abitibi Greenstone Belt, Superior Province, Can. J. Earth Sci., 26, 1747-1763, 1989.

Comell, D. H., and S. S. Schütte, A volcanic-exhalative origin for the world's largest (Kalahari) manganese field. Miner. Deposita, 30 146-151, 1993.

Danielson, A., P. Möller, and P. Dulski, The europium anomalies in banded iron formations and the thermal history of the oceanic crust Chem. Geol., 97, 89-100, 1992.

Dann, J. C., K. R. Chamberlain, and S. A. Bowring, An Early Proterozoic ophiolite, central Arizona: U-Pb constraints on is structures and development (abstract), Geol. Soc. Am. Abstr. Programs, 21, 23, 1989.

Davis, D. W., and M. C. Jackson, Geochronology of the Lumby Lake Greenstone Belt: A 3 Ga complex within the Wabigoon subprovince, northwest Ontario, Geol. Soc. Am. Bull., 100, 818-824, 1988.

de Ronde, C., M. de Wit, and E. T. C. Spooner, Early Archean (> 3.2 Ga) Fe-oxjde-rich, hydrothermal discharge vents in the Barberton greenstone belt, South Africa, Geol. Soc. Am. Bull., 106, 86-104, 1994.

Derry, L. A., and S. B. Jacobsen, The chemical evolution of Precambrian seawater: Evidence from REEs in banded iron formation, Geochim. Cosmochim. Acla, 54, 2965-2977, 1990

Desrochers, J. P., C. Hubert, J. N. Ludden, and P. Pilote, Accretion of Archean oceanic platean fragments in the Abitibi greenstone belt, Geology, 21, 451-454, 1993.

deWit, M. J., C. Roering, R. J. Hart, R. A. Armstrong, C. E. J. de Ronde, R.W.E. Green, M. Tredoux, E. Peberdy, and R. A. Hart, Formation of an Archean continent, Nature, 357, 553-562, 1992.

Dostal, J., and W. U. Mueller, Komatiite flooding of a rifted Archean thyolite arc complex: Geochemical signature and tectonic significance of the Stoughton-Roquemaure Group, Abitib Greenstone Belt, Canada, J. Geol., 105, 545-563, 1997.

Dymek, R. F., and C. Klein, Chemistry, petrology and origin of banded iron-formation lithologies from the $3800 \mathrm{Ma}$ lsua Supracrustal Belt, west Greenland, Precambrian Res., 39, 247-302, 1988.

Eriksson, K. A., B. Krapez, and P. W. Fralick, Sedimentology of Archean greenstone belts: Signatures of tectonic evolution, Earth Sci. Rev., 37, 1-88, 1994.

Ernst, R. E., J. W. Head, E. Parfitt, E. Grosfils, and L. Wilson, Gian radiating dyke swarms on Earth and Venus, Earth Sci. Rev., 39, 1$58,1995$.

Fletcher, I. R., W. G. Libby, and K. J. K. Rosman, Geological note: SmNd dating of the 2411 Jimberlana Dyke, Aust. J. Earth Sci., 34, 523$525,1987$.

Fryer, B. J., Rare earth evidence in iron-formations for changing Precambrian oxidation states, Geochim. Cosmochim. Acta, 41, 361367, 1977.

Gariépy, C., C. J. Allègre, and J. Lajoie, U-Pb systematics in single zircons from the Pontiac sediments, Abitibi Greenstone Belt, Cam J. Earth Sci., 21, 1296-1304, 1984

Garland, F. S., S. Turner, and C. Hawkesworth, Shifts in the source of the Parana basalts through time, Lithos, 37, 223-243, 1996.

Goldstein, S. L., N. T. Arndt, and R. F. Stallard, The history of a continent from $\mathrm{U}-\mathrm{Pb}$ ages of zircons from Orinoco River sand and Sm-Nd isotopes in Orinoco Basin river sediments, Chem. Geol., 139, 271-286, 1997.

Gole, M. J., and C. Klein, Banded iron-formations through much of Precambrian time, J. Geol., 89, 169-183, 1981.

Goodwin, A. M., Archaean volcanogenic iron-formation of the Canadian shield, Sci. Terre, 9, 23-34, 1973.

Graf, J. L., Rare earth elements, iron formations and sea water, Geochim Cosmochim Acta, 42, 1845-1850, 1978.

Gross, G. A., Geology of iron deposits in Canada. I. General geology and evaluation of iron deposits, Econ. Geol. Rep. Geol. Surv. Can. 22, 181, 1965.
Gross, G. A., Tectonic systems and the deposition of iron-formation. Precambrian Res., 20, 171-187, 1983.

Gruau, G., H. Martin, B. Leveque, R. Capdevila, and A. Marot, Rb-Sr and Sm-Nd geochronology of lower Proterozoic granite-greenstone Terrains in French Guiana, South America, Precambrian Res., 30, 63-80, 1985.

Haggerty, S. E., Superkimberlites, Earth Planet. Sci. Lett., 122, 57-69, 1994.

Hassler, S. W., Depositional history of the main tuff interval of the Wittenoom Formation, Late Archean-early Proterozoic Hamersley Group, Western Australia, Precambrian Res., 60, 337-359, 1993.

Heaman, L. M. Global mafic magmatism at $2.45 \mathrm{Ga}$ : Remnants of an ancient large igneous province?, Geology, 25, 299-302, 1997.

Heaman, L. M., and J. Tarney, U-Pb baddeleyite ages for the Scourie dyke swarm, Scotland: Evidence for two distinct intrusion events, Nature, 340, 705-708, 1989.

Heaman, L. M., N. Machado, T. E. Krogh, and W. Weber, Precise U-Pb zircon ages for the Molson Dyke Swarm and the Fox River Sill: Constraints for Early Proterozoic crustal evolution in northeastern Manitoba, Canada, Contrib. Mineral. Petrol., 94, 82-89, 1986.

Hoffman, P. E., United plates of America, the birth of a craton: Early Proterozoic assembly and growth of Laurentia, Ann. Rev. Earth Planet. Sci., 16, 543-603, 1988.

Holland, H. D., The oceans: A possible source of iron in ironformations, Econ. Geol., 68, 1169-1172, 1973 .

Huhma, H., R. A. Cliff, V. Perttunen, and M. Sakko, Sm-Nd and $\mathrm{Pb}$ isotopic study of mafic rocks associated with Early Proterozoic continental rifting: The Peräpohja Schist Belt in northern Finland, Contrib. Mineral. Petrol., 104, 369-379, 1990

Hunter, D. R., and D. L. Reid, Mafic dyke swarms in southern Africa, in Mafic Dyke Swarms, edited by H. C. Halls and W. F. Fahrig, Spec. Pap. 34, Geol. Assoc. Can., 445-456, 1987.

Hynes, A. F., and D. M. Francis, A transect of the Early Proterozoic Cape Smith Foldbelt, new Quebec, Tectonophysics, 88, 23-59, 1982.

Isachsen, C. E., and S. A. Bowring, Evolution of the Slave Craton, Geology, 22, 917-920, 1994

Isley, A. E., Hydrothermal plumes and the delivery of iron to banded iron formation, J. Geol., 103, 169-185, 1995 .

Jackson, S. L., J. A. Fyon, and F. Corfu, Review of Archean supracrustal assemblages of the southern Abitibi greenstone belt in Ontario, Canada: Products of microplate interaction within a large-scale plate-tectonic setting, Precambrian Res., 65, 183-205, 1994.

Jacobsen, S. B., and M. R. Pimentel-Klose, A Nd isotopic study of the Hamersley and Michipicoten banded iron formations: The source of REE and Fe in Archean oceans, Earth Planet. Sci. Lett., 87, 29-44, 1988 .

Jahn, B.-M., and W. G. Emst, Late Archean Sm-Nd isochron age for mafic-ultramafic supracrustal amphibolites from northeastem SinoKorean craton, China, Precambrian Res., 46, 295-306, 1990.

James, H. L, Sedimentary facies of iron-formations, Econ. Geol., 49, 235-293, 1954.

James, H. L., Chemistry of the iron-rich sedimentary rocks, U.S. Geol. Surv. Prof. Pap. 440-W, 61 PP., 1966.

James, H. L, and A. F. Trendall, Banded iron formation: distribution in time and paleoenvironmental significance, in Mineral Deposits and the Evolution of the Biosphere, edited by H. D. Holland and M. Schidlowski, pp. 199-218, Springer-Verlag, New York, 1982.

Kalsbeek, F., and P. N. Taylor, Age and origin of Early Proterozoic dolerite dykes in south-west Greenland, Contrib. Mineral. Petrol., 89, 307-316, 1985.

Kalsbeek, F., and P. N. Taylor, Chemical and isotopic homogeneity of a $400 \mathrm{~km}$ long basic dyke in central west Greenland, Contrib. Mineral. Petrol., 93, 439-448, 1986.

Kalsbeek, F., D. Bridgewater, and H. P. Zeck, A $1950 \pm 60 \mathrm{Ma} \mathrm{Rb-Sr}$ whole-rock age from two Kangâmiut dykes and the timing of the Nagssugtoquidian (Hudsonian) Orogeny in west Greenland, Can. $J$. Earth Sci., 15, 1122-1128, 1978.

Kamo, S. L., and D. W. Davis, Reassessment of Archean crustal development in the Baberton Mountain Land, South Africa, based on U-Pb dating, Tectonics, 13, 167-192, 1994.

Karl, D. M., G. M. McMurtry, A. Malahoff, and M. O. Garcia, Loihi Seamount, Hawaii: A mid-plate volcano with a distinctive hydrothermal system, Nature, 335, 532-535, 1988.

Klasner, J. S., W. F. Cannon, and R. W. Ojakangas, Segment 2--Geology of the Marquette Range Supergroup and the Penokean fold belt in northem Michigan, Pp. 19-31 in: Guidebook for the 28th Internat. Geol. Congr. Fieldirip, Washington, D.C., 1989.

Klein, C., and N. J. Beukes, Time distribution, stratigraphy, and sedimentologic setting, and geochemistry of Precambrian ironformations, in The Proterozoic Biosphere: A Multidisciplinary Approach, edited by J. W. Schopf and C. Klein, Pp. 139-147, Cambridge Univ. Press, New York, 1992.

Klinkhammer, G., and A. Hudson, Dispersal pattems for hydrothermal plumes in the South Pacific using manganese as a tracer, Earth Planet. Sci. Lett., 79, 241-249, 1986. 
Korsch, M. J., and B. L. Gulson, Nd and $\mathrm{Pb}$ isotopic studies of an Archean layered mafic-ultramafic complex, Westem Australia, and implications for mantle heterogeneity, Geochim. Cosmochim. Acta. 50, 1-10, 1986.

Krapez, B., Sequence stratigraphy of the Archean supracrustal belis of the Pilbara block, westem Australia, Precambrian Res., 60, 1-45, 1993.

Krill, A. G., S. Bergh, I. Lindahl, E. W. Meams, M. Often, S. Olerud, J. S. Sandstad, A. Siedlecka, and A. Stolli, Rb-Sr, U-Pb, Sm-Nd isotopic dates from Precambrian rocks of Finnmark, Bull. Norges Geol. Unders., 403, 37-54, 1985.

Kröner, A., and A. Tegtmeyer, Gneiss-greenstone relationships in the Ancient Gneiss complex of southwestem Swaziland, southem Africa, and implications for early crustal evolution, Precambrian Res., 67, 109-139, 1994.

Kusky, T. M., and W. S. F. Kidd, Remnants of an Archean oceanic plateau, Belingwe greenstone belt, Zimbabwe, Geology, 20, 43-46, 1992.

Lahaye, Y., N. Amdt, G. Byerly, C. Chauvel, S. Fourcade, and G. Gruau, The influence of alteration on the trace-element and $\mathrm{Nd}$ isotopic compositions of komatiites, Chem. Geol., 126, 43-64, 1995.

Lamber, M. B., Anatomy of a greenstone beli; Slave Province, N.W.T., Geol. Assoc. Can. Spec. Pap., 16, 331-340, 1977.

Lanyon, R., L. P. Black, and H.-M. Seitz, U-Pb zircon dating of a mafic dyke swarm within the Vestfold Hills, East Antarctica (abstract), in Structural and Metamorphic Studies in High-Grade Metamorphic Terrains, Spec. Group in Tectonics and Stnuct. Geol., Melboume, Victoria, Australia, 1992.

Larson, R. L., Latest pulse of Eanh: Evidence for a mid-Cretaceous superplume, Geology, 19, 547-550, 1991 a.

Larson, R. L., Geological consequences of superplumes, Geology, 19, 963-966, 1991b.

Layer, P. W., A. Kröner, M. McWilliams, and A. Burghele, Paleomagnetism and age of the Archean Ushushwana Complex, southem Africa, J. Geophys. Res., 93, 449-457, 1988.

LeCheminant, A. N., and L. M. Heaman, Mackenzie igneous events Canada: Middle Proterozoic hotspot magmatism associated with ocean opening, Earth Planet. Sci. Lett., 96, 38-48, 1989.

LeCheminant, A. N., L. M Heaman, O. van Breeman, R. E. Emst, W. R. A. Barager, and $K$. L. Buchan, Mafic magmatism, mantle roots and kimberlites in the Slave Craton, in Searching for Diamonds in Canada, edited by A. N. LeCheminant, et al., Open File 3228, pp. 161-169, Geol. Surv. of Can., Otawa, 1996.

Lindenmayer, Z. G., Salobo Sequence, Carajasigma, Brazil: Geology, geochemistry and metamorphism, Doctoral disseration, Univ. West. Ont., London, 1990.

Litule, S. A., K. D. Stolzenbach, and R. P. Herzen, Measurements of plume flow from a hydrothermal vent field, $J$. Geophys. Res., 92, 2587-2596, 1987.

Lobach-Zhuchenko, S. B., E. V. Bibikova, V. P. Chekulaev, and G. M. Drugova, Geochronology and petrology of the Tupa-Goobsky Igneous Complex of the northwest Belomorian mobile belt (abstract), Terre Nova, 6, Suppl. 2, 11, 1994.

Lucas, S. B., and M. R. St. Onge, Terrane accretion in the intemal zone of the Ungava Orogen, northem Quebec, 2, Structural and metamorphic history, Can. J. Earth Sci., 29, 765-782, 1992.

Lupton, J. E., A far-field hydrothermal plume from Loihi Seamount. Science, 272, 976-979, 1996.

Lupton, J. E., and H. Craig, A major helium-3 source at $15^{\circ} \mathrm{S}$ on the East Pacific Rise, Science, 214, 13-18, 1981.

Lupton, J. E., J. R. Delaney, H. P. Johnson, and M. K. Tivey, Entrainment and vertical transport of deep-ocean water by buoyant hydrothermal plumes, Nature, 316, 621-623, 1985.

Machado, N. and M. Cameiro, A major Archean tectonothermal event in the Saõ Francisco shield, Brazil: U-Pb evidence from the Bonfim Metamorphic Complex, Quadrilátero Ferrífero, Minas Gerais, Can. J. Earth Sci., 29, 2341-2346, 1992.

Machado, N., Z. Lindenmayer, T. E. Krogh, and D. Lindenmayer, U-Pb geochronology of Archean magmatism and basement reactivation in the Carajás area, Amazon Shield, Brazil, Precambrian Res., 49, 329-354, 1991.

Machado, N., C. M. Noce, E. A. Ladeira, and O. Belo de Oliveira, U-Pb geochronology of Archean magmatism and Proterozoic metamorphism in the Quadrilatero Ferrifero, southem Saô Francisco Craton, Brazil, Geol. Soc. Am. Bull., 104, 1221-1227, 1992.

McNaughton, N. J., W. Compston, and M. E. Barley, Constraints on the age of the Warrawoona Group, eastem Pilbara block. Westem Australia, Precambrian Res., 60, 69-98, 1993.

Morey, G. B., and D. L. Southwick, Allostratigraphic relationships of Early Proterozoic iron-formations in the Lake Superior region, Econ. Geol., 90, 1983-1993, 1995.

Morris, R. C, Genetic modelling for banded iron-formation of the Hamersley Group, Pilbara Craton, western Australia, Precambrian Res., 60, 243-286, 1993.

Montensen, J. K., U.Pb geochronology of the eastem Abitibi subprovince, 2, Noranda-Kirkland Lake area, Can. J. Earth Sci., 30, $29-41,1993$.
Murthy, N., Maric dyke swarms of the Indian Shield, in Mafic Dyke $S$ warms, edited by H. C. Halls and W. F. Fahrig, Spec. Pap. 34, Geol. Assoc. Can., 393-400, 1987.

Murty, Y. G. K., V. Babu Rao, D. Guptasarma, M. N. Rao, and S. Bhattacharji, Tectonic, petrochemical and geophysical studies of mafic dyke swarms areound the Proterozoic Cuddapah Basin, south India, in Mafic Dyke Swarms, edited by H. C. Halls and W. F. Fahrig, Spec. Pap. 34, Geol. Assoc. Can., 303-316, 1987.

Nelsen, T. A., G. P. Klinkhammer, J. H. Trefry, and R. P. Trocine, Realtime observation of dispersed hydrothermal plumes using nephelometry examples from the Mid-Atlantic Ridge, Earth Planet. Sci. Lett., 81, 245-252, 1986.

Nelson, D. R., A. F. Trendall, J. R. de Laeter, N. J. Grobler, and I. R. Fletcher, A comparative study of the geochemical and isotopic systematics of Late Archaean flood basalts from the Pilbara and Kaapvaal cratons, Precambrian Res., 54, 231-256, 1992.

Nisbet, E. G., et al., Uniquely fresh $2.7 \mathrm{Ga}$ kormatiites form the Belingwe Greenstone Belt, Zimbabwe, Geology, 15, 1147-1150, 1987.

Noble, S. R, and P. C. Lightfoot, U-Pb baddeleyite ages of the Kerns and Triangle Mountain intrusions, Nippissing Diabase, Ontario, Can. J. Earth Sci., 29, 1424-1429, 1992.

Oen, I. S., Rift-related igncous activity and metallogenesis in SW Bergslagen, Sweden, Precambrian Res., 35, 367-382, 1987.

Oyarzun, R. M. Doblas, J. Lopez-Ruiz, and J. M. Cebriá, Opening of the central Atlantic and asymmetric mantle upwelling phenomena: Implications for long-lived magmatism in western North Africa and Europe, Geology, 25, 727-730, 1997.

Pan, Y., and M. E. Fleet, Geochemistry and origin of cordieriteorhoamphibole gneiss and associated rocks at an Archean volcanogenic massive sulfide camp: Manitouwadge, Ontario, Canada, Precambrian Res., 74, 73-89, 1995.

Parrish, R. R., U-Pb geochronology of the Cape Smith Belt and Sugluk Block, northem Quebec, Geosci. Can., 16, 126-130, 1989.

Percival, J. A. R. A. Stem, K. D. Card and J. K. Mortensen, Northeastem Superior Province: Missing link in describing tectonic assembly of the craton at $2.7 \mathrm{Ga}$, Geol. Soc. Am. Abstr. Programs, $25,236,1993$.

Pidgeon, R. T., and R. C. Horwitz, The origin of olistoliths in Proterozoic rocks of the Ashburton Trough, westem Australia, Aust. J. Earth Sci., 38, 55-63, 1991.

Pidgeon, R. T., and S. A. Wilde, The distribution of $3.0 \mathrm{Ga}$ and $2.7 \mathrm{Ga}$ volcanic episodes in the Yilgam Craton of Westem Australia, Precambrian Res., 48, 309-325, 1990.

Pinho, F. E. W. S. Fyfe, and M. A. S. B. Pinho, Early Proterozoic evolution of the Alto Jaura Greenstone Belt, southem Amazonia craton, Brazil, Int. Geol. Rev., 39, 220-229, 1997.

Pouba, Z., and B. Kribek, Organic matter and the concentration of metals in Precambrian stratiform deposits of the Bohemian Massif, Precambrian Res., 33, 225-237, 1986.

Poujol, M., L. J. Robb, J.-P. Respaut, and C. R. Anhaeusser, 3.07-2.97 Ga greenstone belt formation in the northeastem Kaapvaal Craton: implications for the origin of the Witwatersrand Basin, Econ. Geol. 91, 1455-1461, 1996.

Premo, W. R., R. T. Helz, M. L. Zientek, and R. B. Langston, U-Pb and Sm-Nd ages for the Stillwater Complex and its associated sills and dikes, Beartooth Mountains, Montana: Identification of a parent magma?, Geology, 18, 1065-1068, 1990.

Puchtel, I. S., D. Z. Zhuravlev, V. S. Kulikov, and V. V. Kulikova, Petrology and Sm-Nd age of a differentiated komatiitic basalt lava flow in the Vetreny Belt, Baltic Shield, Geochem. Int., 28, 14-23, 1991.

Puchtel, I. S., K. M. Haase, A. W. Hofmann, C. Chauvel, V. S. Kulikov, C.-D. Garbe-Schönberg, and A. A. Nemchin, Petrology and geochemistry of crustally contaminated komativic basalts from the Vetreny Belt, southeastem Baltic Shield: Evidence for an Early Proterozoic mantle plume beneath rified Archean continental lithosphere, Geochim. Cosmochim. Acta, 61, 1205-1222, 1997a.

Puchuel, I. S., A. W. Hofmann, K. P. Jochun, K. Mezger, A. A. Shchipanskiy, and A. V. Samsonov, The Kostomuksha Greenstone Belt, NW Baltic Shield: A remnant of a Late Archean oceanic plateau?, Terra Nova, 9, 87-90, $1997 \mathrm{~b}$.

Puchtel, I. S., N. T. Amdt, A.W. Hofmann, K. M. Hasse, A. Kröner, V. S. Kulikov, V. V. Kulikova, C. D. Garbe-Schönberg, and A. A Nemchim, Petrology of mafic lavas within the Onega Plateau central Karelia: Evidence for the $2.0 \mathrm{Ga}$ plume-related continental crustal growth in the Baltic Shield, Contrib. Mineral. Petrol., in press, 1999.

Pyke, D. R., Geology of the Timmins area, District of Cochrane, Ont. Geol. Surv. Rep., 219, 141 Pp., 1982.

Radhakrishna, T., G. V. S. Poomachandran, J. G. Mitchell, and R. Venkatesh, Proterozoic basic dyke activity in Kerala along the westem continental margin of India, J. Geol. Soc. India, 27, 245253, 1986.

Rampino, M. R., and K. Caldeira, Major episodes of geological change: Correlations, time structure and possible causes, Earth Planet. Sci. Let.., 114, 215-227, 1993. 
Reymer, A., and G. Schubert, Rapid growth of some major segments of continental crust, Geology, 14, 299-302, 1986.

Richards, M. A., R A. Duncan, and V. E. Courtillo, Flood basalts and hot-spot tracks: Plume heads and tails, Science, 246, 103-107, 1989.

Richards, M. A., D. L Jones, R. A. Duncan, and D. J. DePaolo, A mantle plume initiation model for the Wrangellia flood basalt and other oceanic plateaus, Science, 254, 263-267, 1991.

Rona, P. A., Hydrothermal mineralization at seafloor spreading centers, Earlh Sci.Rev., 20, 1-104, 1984.

Sakko, M., and $\mathrm{K}$. Laajoki, Whole rock $\mathrm{Pb}-\mathrm{Pb}$ isochron age for the Paakko iron formation in Vayrylankyla, south Puolanka a rea, Finland, Bull. Geol. Soc. Finl., 47, 113-116, 1975.

Sharkov, E. V., et al., Petrology and $\mathrm{Ni}$-Cu-Cr-PGE mineralization of the langest mafic pluton in Europe: The Early Proterozoic Burakovsky layered introsuion, Karelia, Russia, Internat. Geol. Rev., 37, 509. $525,1995$.

Shchipansky, A. A., and S. V. Bogdanova, The Sarmatian crustal segment: Precambrian correlation between the Voronezh Massif and the Ukranian Shield across the Dneiper-Donets Aulocogen, Tectonophysics, 268, 109-125, 1996.

Sheraton, J. W., and L. P. Black, Geochemistry and geochronology of Proterozoic tholeiite dykes of East Antactica: Evidence for mantle metasomatism, Contrib. Mineral. Petrol., 78, 305-317, 1981.

Simonson, B. M., Sedimentological constraints on the origins of Precambrian iron-formations, Geol. Soc. Am. Bull., 96, 244-252, 1985.

Simonson, B. M., and S. Hassler, Was the deposition of large Precambrian iron formations linked to major marine transgressions?, J. Geol., 104, 665-676, 1996

Sims, P. K., W. R. Van Schmus, K. J. Schultz, and Z. E. Peterman, Tectonostratigraphic evolution of the Early Proterozoic Wisconsin magmatic terranes of the Penokean Orogen, Can.J. Earth Sci., 26, 2145-2158, 1989

Sims, P. K., K. J. Schultz, E. DeWin, and B. Brasaemle, Petrology and geochemistry of Early Proterozoic granitoid rocks in Wisconsin magmatic terranes of Penokean Orogen, northem Wisconsin, U.S. Geol. Swrv. Bull., 8755-531X, J1-J31, 1993.

Skufin, P. K., The orogenic picrite-andesitic volcanism of the southem Pechenga zone, Kola Basin, Russia (abstract), Terra Nova, 6, Suppl. $2,17,1994$

Skulski, T., and J. A. Percival, Allochthonous $2.78 \mathrm{Ga}$ oceanic plateau slivers in a $2.72 \mathrm{Ga}$ continental arc sequence: Vizien Greenstone Belt, northwestem Superior Province, Canada, Lithos, 37, 163-179. 1996.

Smith, H. S., Early Precambrian basic rocks of Africa, in Early Precambrian Basic Magmatism, edited by R. P. Hall and D. J. Hughes, pp. 352-378, Chapman and Hall, New York, 1990.

Speer, K. A., and P. A. Rona, A model of an Atlantic and Pacific hydrothermal plume, J. Geophys. Res., 94, 6213-6220, 1989.

Stem, R. A., J. A. Percival, and J. K. Mortensen, Geochemical evolution of the Minto Block: A $2.7 \mathrm{Ga}$ continental magmatic arc built on the Superior proto-craton, Precambrian Res., 65, 115-153, 1994.

Steuber, A. M., R A. Heimlich, and M. Ikamuddin, Rb-Sr ages of Precambrian mafic dikes, Bighom Mountains, Wyoming, Geol. Soc. Am. Bull., 87, 909-914, 1976.

Stevenson, R., Crust and mantle evolution in the Late Archean: Evidence from a Sm-Nd study of the North Spirit Lake Greenstone Belt, northwestem Ontario, Canada, Geol. Soc. Am. Bull., 107, 1458$1467,1995$.

St. Onge, M. R., S. B. Lucas, and R. R. Parrish, Terrane accretion in the internal zone of the Ungava orogen, northem Quebec, 1 , Tectonostratigraphic assemblages and their tectonic implications, Can. J. Earth Sci., 29, 746-764, 1992.

Storey, M., J. J. Mahoney, L. W. Kroenke, and A. D. Saunders, Are oceanic plateaus sites of komatiite formation?, Geology, 19, 376$379,1990$.

Taylor, S. R, and S. M. Mclennan, The Continental Crust: Its Composition and Evolution, 312 pp., Blackwell Scientific Publications, Malden, Mass., 1985.

Thorne, A. M., and T. S. Blake, Fortescue Group, Third International Archaean Symposium, edited by S. E. Ho et al., Pp. 14-18, Univ. West Aust. Publ., Perth, 1990.

Trendall, A. F. Three great basins of Precambrian banded iron formation deposition: A systematic comparison, Geol. Soc. Am. Bull., $79,1527-1544,1968$.

Trendall, A. F., and J. G. Blockley, The iron formations of the Precambrian Hamersley Group, Western Australia, with special reference to the associated crocidolite, Bull. 199, West. Aust. Geol. Surv., 1970.

Trendall, A.F., et al., Precise zircon U-Pb chronological comparison of the volcano-sedimentary sequences of the Kaapvaal and Pilbara cratons between about 3.1 and $2.4 \mathrm{Ga}$, paper presented at Third Intemational Archean Symposium, Univ. of West Aust, Perth, 1990.

Tsomondo, J. M., J. F. Wilson, and T. G. Bleinkinsop, Reassessment of the structure and stratigraphy of the Early Archean Selukwe Nappe, Zimbabwe, paper presented at Third Intemational Archean Symposium, Univ. of West Aust., Perth, 1990.
Turek, A., P. E. Smith, and W. R. van Schmus, Rb-Sr and U-Pb ages of volcanism and granite emplacement in the Michipicoten Belt-Wawa, Ontario, Can.J. Earth Sci., 19, 1608-1626, 1982.

Tumock, A. C. D. L. Trueman, R. J. Spenser, and I-M. Chou, Ironstones of mixed sedimentary and hydrothermal origin in the Archean greenstone belt at Bird Lake, Manitoba; Fluid-mineral interactions, Spec. Publ. Geochem. Soc., 2, 143-155, 1990.

Tyler, I. M., and A. M. Thome, The northem margin of the Capricom Orogen, Westem Australia--An example of an Early Proterozoic collision zone, J. Struct. Geol., 12, 685-701, 1990.

Van Schmus, W. R., and M. E. Bickford, Proterozoic chronology and evolution of the midcontinent region, North America, in Precambrian Plate Tectonics, edited by A. Kröner, 261-296, Elsevier, New York, 1981.

Veizer, J. Geologic evolution of the Archean-Early Proterozoic Earth in Earth's Earliest Biosphere, edited by J. W. Schopf, pp. 240-259, Princeton University Press, Princeton, N.J., 1983.

Velikoslavinsky, S. D., E. V. Tolmacheva, V. L. Dook, R. I. Milkevich, and V. A. Rudnick, Geochemical mapping of basic complexes in the Early Precambrian Aldan-Stanovoy Shield of Siberia, Precambrian Res., 62, 507-525, 1993.

Vidal, P., S. Blais, B.-M. Jahn, and R Capdevila, U-Pb and Rb-Sr systematics of the Suomussalmi Archean greenstone Belt (eastem Finland), Geochim. Cosmochim. Acla, 44, 2033-2044, 1980.

Walker, J. C., C. Klein, M. Schidlowski, J. W. Schopf, D. J. Stevenson, and $M$. R. Walter, Environmental evolution of the Archean-Early Proterozoic Earth, in Earth's Earliest Biosphere, edited by J. W. Schopf, pp. 260-290. Princeton University Press, Princeton, N.J., 1983.

Walraven, F., and J. Martini, Zircon Pb-evaporation age determinations for the Oak Tree Formation, Chuniespoon Group, Transvaal sequence: Implications for Transvaal-Griqualand West basin correlations, S. Afr. J. Geol., 98, 58-67, 1995.

Walraven, F., R. A. Armstrong, and F. J. Kruger, A chronostratigraphic framework for the north-central Kaapvaal craton, the Bushveld Complex and the Vredefort structure, Tectonophysics, 171, 23-48, 1990 .

Wang, O., L. Schiotte, and I. H. Campbell, Geochronological constraints on the age of komatiites and nickel mineralization in the Lake Johnston Greenstone Belt, Yilgam Craton, Westem Australia, Aust. J. Earth Sci., 43, 381-385, 1996.

Wang, $X$., U/Pb zircon geochronology study of the Bird River Greenstone Belt, southeastem Manitoba, Master's thesis, 109 pp., Univ. of Windsor, Windsor, Ont., Canada, 1993.

Wardle, R. J., B. Ryan, G. A. G. Nunn, and F. C. Mengel, Labrador segment of the Trans-Hudson Orogen: Crustal development through oblique convergence and collision, in The Early Proterozoic Trans. Hudson Orogen of North America, edited by J. F. Lewry and M. R. Stauffer, Geol. Assoc. Can. Spec. Pap., 37, 353-369, 1990.

White, R. S., and D. P. Mackenzie, Magmatism at rift zones: The generation of volcanic continental margins and flood basalts, $J$. Geophys. Res., 94, 7685-7729, 1989.

Wikstrom, A., T. Skiold, B. Ohlander, and T. S. Brewer, The relationship between $1.88 \mathrm{Ga}$ old magmatism and the Baltic-Bothnian shear zone in northern Sweden, in Precambrian Crustal Evolution in the North Atlantic Region, edited by T.S. Brewer, Geol. Soc. Spec. Publ., 112, 249-259, 1996.

Wilson, A. H., and R. W. Carison, A Sm-Nd and Pb isotope study of Archaean greenstone belts in the southem Kaapvaal Craton, South Africa, Earth Planet. Sci. Lett., 96, 89-105, 1989.

Wilson, A. H., and M. D. Prendergast, The Great Dyke of Zimbabwe, I tectonic setting, stratigraphy, petrology, structure, emplacement and crystallization, in Magmatic Sulfides--Zimbabwe Volume, edited by M. D. Prendergast and M.J. Jones, pp. 1-20, London, Inst. of Min. and Metall., 1989.

Wilson, A. H., and J. A. Versfeld, The early Archaean Nondweni Greenstone Belt, southern Kaapvaal Craton, South Africa, II, Characteristics of the volcanic rocks and constraints on magma genesis, Precambrian Res., 67, 277-320, 1994.

Windom, K. E., W. R. van Schmus, K. E. Seifert, E. T. Wallin, and R. R. Anderson, Archean and Proterozoic tectonomagmatic activity along the southem margin of the Superior Province in northwestern Iowa, United States, Can.J. Earth Sci., 30, 1275-1285, 1993.

Winter, H. de la R., A lithostratigraphic classification of the Ventersdorp succession, Trans. Geol. Soc. S. Afr., 79, 31-48, 1976.

Wise, D. U., Continental margins, freeboard, and the volumes of continental crust, in The Geology of Continental Margins, edited by C. A. Burk and C. L. Drake, pp. 45-58, Springer-Verlag, New York, 1974.

D. H. Abbott, Lamont-Doherty Earth Observatory of Columbia University, Palisades, New York 10964. (dallas@ideo.columbia.edu)

A. E. Isley, Department of Earth Sciences, State University of New York at Oswego, Oswego, New York 13126. (islev@osweqo.edu)

(Received June 4, 1998; revised February 1, 1999; accepted February 11, 1999.) 